\title{
Modernizing Architecture and Ornament on Mid-Nineteenth-Century Scandinavian Farms
}

\section{Ripatti, Anna}

2019

Ripatti , A 2019 , ' Modernizing Architecture and Ornament on Mid-Nineteenth-Century Scandinavian Farms ' , Journal of the Society of Architectural Historians , vol. 78 , no. 1 , pp. 68-89 . https://doi.org/10.1525/jsah.2019.78.1.68

http://hdl.handle.net/10138/299975

https://doi.org/10.1525/jsah.2019.78.1.68

publishedVersion

Downloaded from Helda, University of Helsinki institutional repository.

This is an electronic reprint of the original article.

This reprint may differ from the original in pagination and typographic detail.

Please cite the original version. 


\title{
Modernizing Architecture and Ornament on Mid-Nineteenth-Century Scandinavian Farms
}

\author{
ANNA RIPATTI \\ University of Helsinki
}

$\mathrm{H}$ istorians have long looked upon railways and factories as the primary symbols of nineteenth-century modernization, yet contemporary sources reveal that farmsteads, too, were central to that process. ${ }^{1}$ In midnineteenth-century Scandinavia, a small, liberal elite of agrarian and architectural reformers-comprising gentlemen farmers, owners of large estates, architects, and civil engineers-launched a vigorous campaign to improve farm architecture for the purposes of feeding a growing population and expanding industry and exports. ${ }^{2}$ They published numerous plans for model farmsteads and encouraged peasants and rural laborers to craft wood decorations for their farm buildings. In Sweden and Finland, the reformers widely regarded farmhouses and their outbuildings as the most important types of structures through which to improve the national economies and promote a modern rural architecture. Wood carvings played a major role not only in the new aesthetic ideal but also in plans for more comprehensive social reform.

By contextualizing the promotion of architectural ornament within debates about rural architectural reform and the condition of the rural poor, I seek to show in this article that ornament served as a means of imagining and planning a model society. Elite Nordic reformers used ornament as a tool for improving the condition of rural inhabitants, increasing agricultural production, encouraging craft as a source of income for the rural poor, spreading civilization and wellbeing, and imposing order in the Scandinavian countryside. Focusing on Sweden and Finland, which the reformers

Journal of the Society of Architectural Historians 78, no. 1 (March 2019), 68-89, ISSN 0037-9808, electronic ISSN 2150-5926. () 2019 by the Society of Architectural Historians. All rights reserved. Please direct all requests for permission to photocopy or reproduce article content through the University of California Press's Reprints and Permissions web page, https://www.ucpress .edu/journals/reprints-permissions, or via email: jpermissions@ucpress.edu. DOI: https://doi.org/10.1525/jsah.2019.78.1.68.

viewed as a unified cultural sphere, I aim to shed light on efforts to promote a united Scandinavia through architecture and, specifically, through architectural ornament.

Nineteenth-century Sweden and Finland were predominantly rural societies. In 1850,90 percent of Sweden's 3.5 million inhabitants were rural; the proportions were similar in Finland, where in 1865 more than 93 percent of the 1.8 million inhabitants were rural dwellers. Peasant farmers and landless agricultural laborers constituted by far the largest part of the population, whereas the number of noble rural estates was quite small. ${ }^{3}$ Referring to the farm architecture of landowning peasants and their laborers, Charles Emil Löfvenskiöld, a Swedish amateur architect and tenant farmer descended from an impoverished noble family, wrote in 1869 that no one could deny the great national importance of the buildings of "these millions of people and their stock, on whose well-being depends the prosperity of Sweden."

Although several historians have examined Löfvenskiöld's attempts to renew farm architecture in Sweden, little attention has been paid either to contemporary discussions of these reforms or to their transnational character. ${ }^{5}$ Meanwhile, while noting the abundance of wood carvings in mid-nineteenthcentury Nordic architecture, historians for the most part have interpreted the carvings as merely decorative, connected to the so-called Swiss style, reflecting either the progress of industrialism or a growing interest in indigenous building traditions. ${ }^{6}$ Such interpretations fail to recognize the meanings of this type of ornament for nineteenth-century reformers, who saw it as capable of regenerating not only architecture but society more generally. Further, while many scholars have considered how the meanings of architectural ornament were changed by the advent of standardized, mechanical mass production and the marketing of prefabricated decorations in catalogues, handicraft and mechanical production were not 


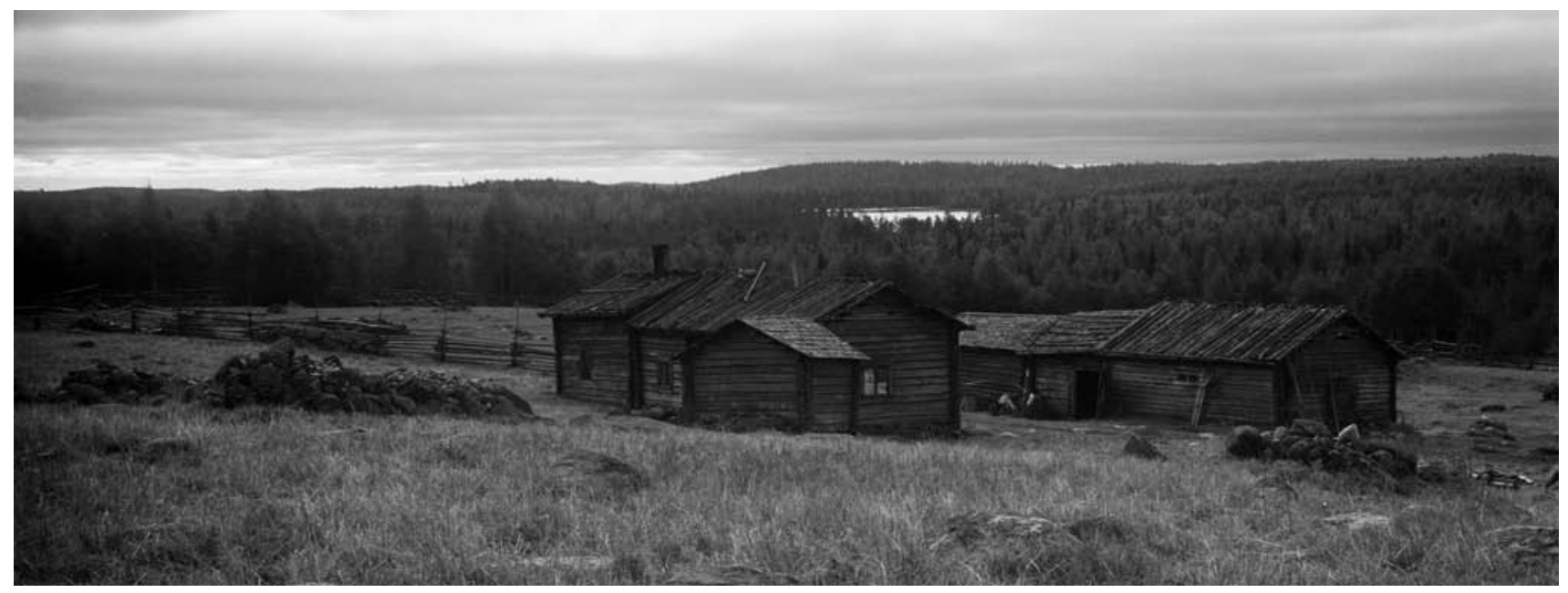

Figure 1 Saastamoinen Farmstead, Maaninka, Finland, as seen in 1927 (photo by Ahti Rytkönen; Ethnographic Picture Collections, The Finnish Heritage Agency).

seen as mutually exclusive in mid-nineteenth-century Scandinavia. ${ }^{7}$ Promoters of architectural ornament there aimed to combine the positive effects of mass production and handicraft and to show that the products of both were vital to building a civilized and prosperous modern society. Treatises on farm architecture and instructions for making wood ornament merged aesthetic and political aspirations, their texts promoting a modern, welfare society that would grow and benefit from wooden architectural ornament. These small and seemingly insignificant decorative details were thus loaded with political significance.

\section{The Impoverished Countryside}

Beginning in the late eighteenth century, Nordic rural communities experienced dramatic physical and organizational changes. In Sweden and Finland (at that time an eastern province of Sweden), a redistribution of land dispersed traditional villages and their once-clustered farmsteads. New farmsteads were built in remote rural areas where landowning peasants held separate parcels, each with its own farmhouse (Figure 1). A further reorganization of farm boundaries occurred in Sweden and Finland (the latter of which became an autonomous grand duchy of the Russian Empire in 1809) in the early nineteenth century. The aim of these reorganizations was to provide more land for cultivation so as to improve agricultural productivity and better feed growing populations. ${ }^{8}$ However, as a consequence of these policies, the number of landless rural poor increased considerably, while the number of peasant farmers, who usually owned the land they cultivated and had relatively high social and economic standing, remained more or less the same. ${ }^{9}$ In Finland especially, rural poverty became widespread as a result of dramatic population growth. ${ }^{10}$
By the mid-nineteenth century, the growing numbers of landless rural laborers in these areas posed a serious problem. At a time when the traditional guild system still regulated industry and trade, and thus stifled the growth of commerce outside towns, agriculture was the main source of income for rural populations. ${ }^{11}$ The prospects of making a decent living from agriculture, however, were diminishing. Many owners of large estates replaced their tenant farmers with seasonal workforces, and, consequently, the social and economic gaps between landowners and the landless widened even further. ${ }^{12}$

The grinding poverty of the landless rural population was widely discussed in the press. Some landowners were convinced that alcohol was to blame. Others believed the problem was rooted in outdated employment contracts and the inadequate wages paid to agricultural workers. Many faulted the custom of paying wages in kind as opposed to cash. ${ }^{13}$ The rise of socialism beginning in the late 1840 s gave special urgency to an already heated debate, although socialist ideas had as yet made few inroads among Nordic rural populations. Alarmed by the prospect of landless rural workers outnumbering landed peasants, many observers saw in the rural poor a threat to the established political and social order. ${ }^{14}$ The future of society thus depended on the well-being and good conduct of the laboring population. Scandinavian writers and politicians, like their counterparts almost everywhere in Europe, began devoting unprecedented attention to the masses.

In the context of these discussions, a new emphasis on modernizing rural societies arose. Such modernization was aimed at increasing agricultural production and improving the lot of the rural poor at a time when poverty was peaking. This activity —initiated by the owners of large estates-led to the launch of several specialized monthly and weekly magazines, the founding of regional agricultural societies and farming schools, and the first agricultural meetings and fairs, 
where new ideas were discussed and information on modern farming was distributed among people of all classes. ${ }^{15}$

These measures proved insufficient in combating poverty, however. Finland's Poor Aid Act of 1852, intended to prevent pauperism and vagrancy, introduced new controls on landless rural laborers, forcing them to submit to the legal guardianship of the landowners for whom they worked. The social and economic position of the rural poor was further weakened by reforms that redefined land-use rights, including restricting the rights of the landless to practice slash-and-burn agriculture. The harms caused by these policies were exacerbated by frequent crop failures, which resulted in the spread of extreme poverty among underemployed seasonal laborers. ${ }^{16}$

Many reformers claimed that legislation restricting the rural production and trade of handicrafts contributed substantially to the increase in rural poverty. Handicraft production, both private and commercial, was a common part-time occupation for peasants, tenant farmers, and landless agricultural laborers alike, especially during the long winter months. Most of this activity, however, was unofficial. Commercialization of rural craft by anyone other than authorized "parish craftsmen" was illegal, even though old laws allowed peasants and rural laborers to make handicrafts "of iron and wood" at home for local sale. ${ }^{17}$ By the 1840 s, liberal reformers began calling for the abolition of these obsolete laws, recognizing that commercial craft could benefit a broad cross section of the rural population. They regarded commercial craft not only as a reasonable secondary occupation for peasant farmers but also as a new primary occupation for many of the rural poor.

As was often the case, reform came first in Sweden, where, in 1846, commercial craft became a legal occupation in the countryside. Finland followed suit in 1856. New legislation guaranteeing freedom of occupation and the encouragement of commercial handicraft production were seen as potentially potent solutions for widespread rural poverty. ${ }^{18}$ Even so, the challenges of improving conditions among the rural poor remained enormous. In one of the new journals dedicated to spreading information on technical and practical inventions, the Finnish gentleman farmer Konstantin von Fieandt spoke for many when he asked:

How can we undertake this reform especially in a country where frost is a daily visitor and stubbornness a national character? In a land where a farmer is isolated, even against his will, like Robinson was on his island, and where his peers don't know much more than that they exist. It is absolutely impossible. ${ }^{19}$

\section{Scandinavian "Agritecture"}

Land reform and the rapid growth in rural populations led to the construction of numerous new farmsteads in nineteenthcentury Scandinavia. There were no official guidelines for building modern farmsteads, but a small circle of large estate owners, architects, and civil engineers recognized the economic, social, and aesthetic opportunities offered by agrarian reform, and they stepped in to help. The publishing industry proved to be a valuable tool in their endeavors.

The need for reform in rural architecture, and in agricultural practices more generally, was a constant cry in the press. In 1850, an anonymous writer in a Finnish newspaper lamented, "Everywhere [in the countryside] one longs for calculation and plan, order and beauty, art in harmony with natural conditions, simplicity and modesty combined with utility and necessity. These observations concern, first of all, architecture. ${ }^{20}$ Such action was one of the main objectives of the first Swedish architectural magazine, Tidskrift för praktisk byggnadskonst och mekanik m.m. (Fournal for Practical Architecture and Mechanics etc., hereafter FPAM), founded in Stockholm in 1850 with the aim of providing plans mainly for rural buildings. Its editors aspired to "ennoble and uplift" the rural environment. ${ }^{21}$

FPAM quickly became a showcase for modern Scandinavian architecture, and particularly for the ideas and plans of Charles Emil Löfvenskiöld, who devoted himself to modernizing Swedish agriculture through architecture. His close contacts with publishers helped him to become the most celebrated figure in the Swedish farm architecture reform movement. In 1854, 7PAM editor in chief Carl Adolf Forselius, who claimed that "the way of building in the countryside lacked insight and attention," launched a separate publication featuring a series of Löfvenskiöld's plans at low cost in order to disseminate them among a wider public. ${ }^{22}$ In 1868 , Löfvenskiöld produced a further series of plans for farm buildings in collaboration with the architect Hjalmar Kumlin (Figure 2). ${ }^{23}$ Published in Swedish, all of these publications, along with other contemporary Nordic agricultural journals, addressed the upper strata of rural society-the landed peasants and gentlemen farmers-most of whom, even those living in Finland, read Swedish.

Löfvenskiöld offered a broad range of plans for modern rural buildings. His unassuming plan for a peasant's or agricultural laborer's farmstead included a dwelling and one outbuilding (Figures 3 and 4). Löfvenskiöld's approach differed from traditional rural practice, particularly in the treatment of buildings for the lower classes. The use of board cladding, roof tiles, wood carvings above doors and windows, and finials on gables had previously been seen almost exclusively in dwellings for the upper classes. Most important, Löfvenskiöld proposed replacing the multiple outbuildings of traditional peasant farmsteads with a single structure designed to house farm animals, implements, and harvested crops alike. His humble, low-priced, moderately decorated plans were meant to improve efficiency and modernize both Scandinavian agriculture and rural architecture. 


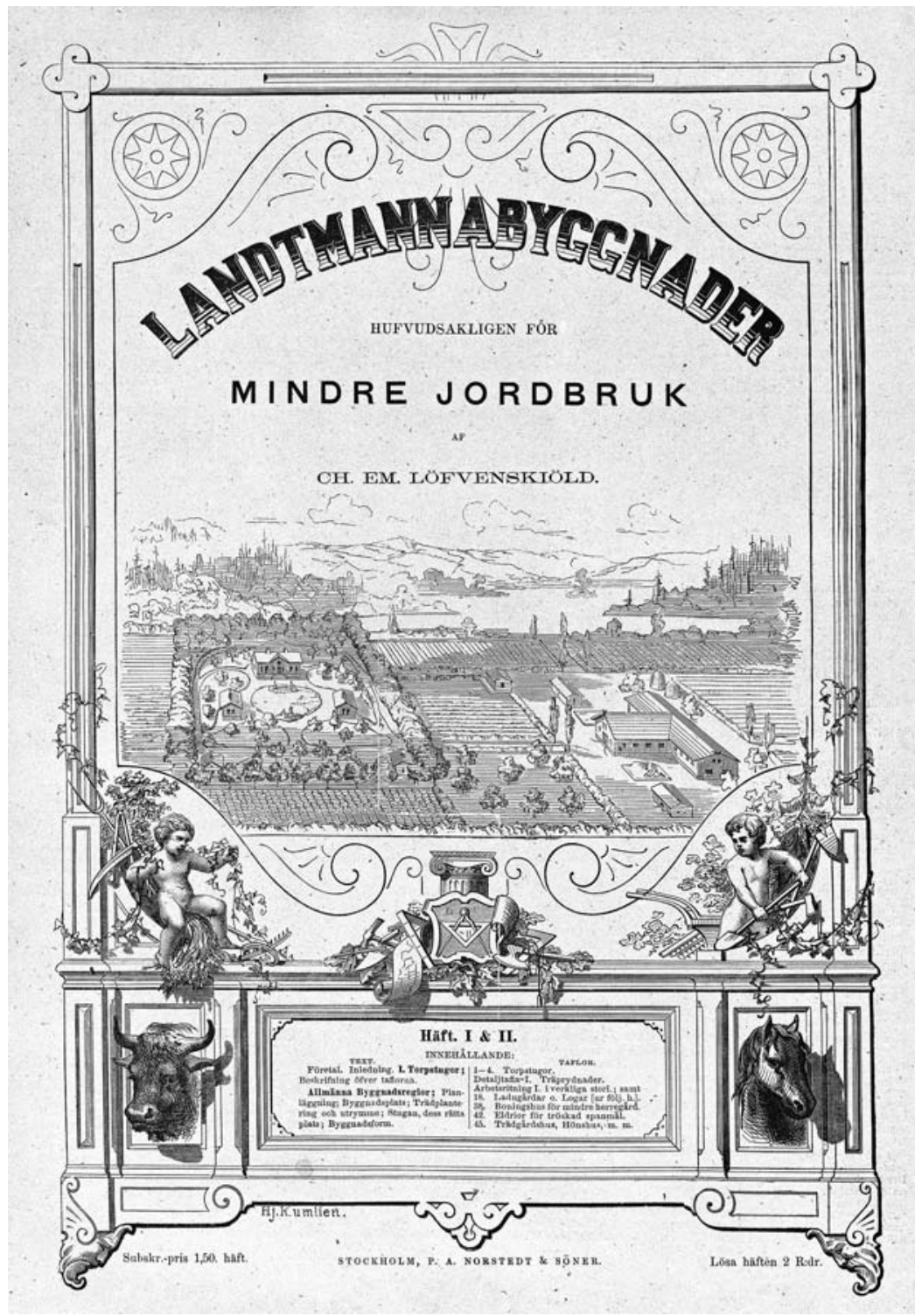

Figure 2 Hjalmar Kumlin, frontispiece for Charles Emil Löfvenskiöld's Landtmannabyggnader hufvudsakligen för mindre jordbruk, 1868 (Stockholm: P. A. Norstedt \& Söner; National Library of Sweden).

Löfvenskiöld's program was a continuation of progressive efforts of the previous century, when Scandinavian gentlemen farmers first conceived of agrarian reform as a moral and patriotic duty. ${ }^{24}$ His work was a late product of "Agromania, or Farming-Phrenzy," an eighteenth-century fashion invigorated by physiocratic ideas. ${ }^{25}$ This transnational movement, building on debates around the political and economic role of agricultural production, produced plans and instructions for building exemplary farmsteads; many of these were published in Sweden from the mid-eighteenth century onward. ${ }^{26}$ In 1797, the French architect François Cointeraux essentialized this reform, in which architecture and agriculture were combined, by coining the new term agritecture. ${ }^{27}$ Numerous "agritectural" publications appeared throughout Europe in the early decades of the nineteenth century, seeking to further the reform movement and market the services of individual architects to potential customers. Their point of departure was to criticize the present state of rural architecture. For instance, in 1805, in his Designs for Cottages, Cottage Farms and Other Rural Buildings, the English architect Joseph Gandy lamented

the vile and almost barbarous taste still existing among Country Builders, which would certainly be improved and corrected, by scattering over the country specimens for imitation, of a superior kind. Good taste would thus be naturalized, and we should not be disgusted (as is so frequently the case) with the appearance of Country Buildings. ${ }^{28}$

The poor state of rural architecture was a source of constant complaint in architectural magazines across Europe. In 1840, in the first issue of his Revue générale de l'architecture et des travaux publics, French architect César Daly bemoaned the deplorable conditions of the dwellings occupied by French farmers; although twenty-two million of them nourished the country and provided raw material for its industries, they 
Figure 3 Charles Emil Löfvenskiöld, farmhouse, 1854 (C. E. Löfvenskiöld, Landtmanna-byggnader [Stockholm: C. A. Forselius, 1854]; Museum of

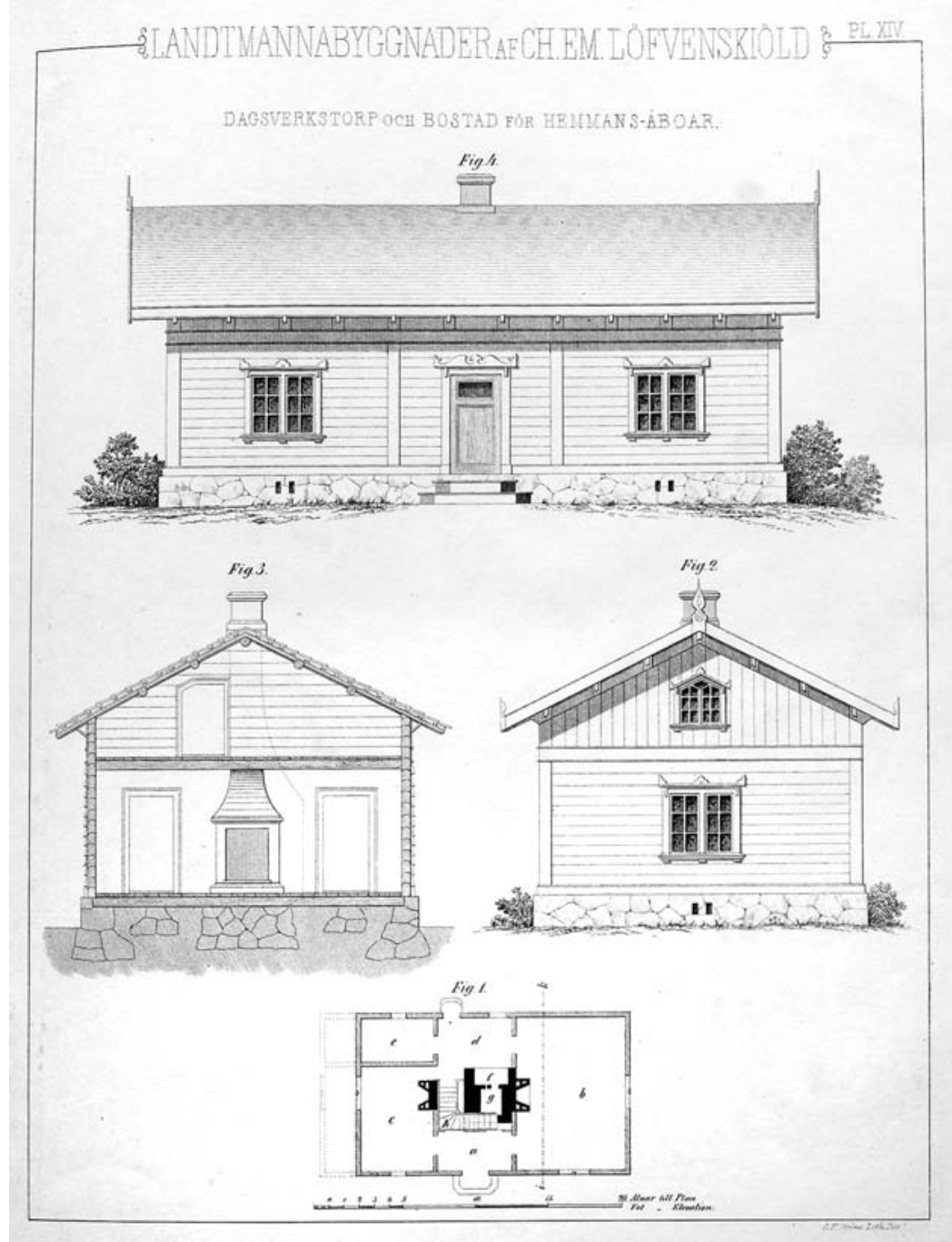

themselves lived in miserable, ugly huts. Elevating agriculture and architecture above all other industries, Daly made it his mission to reform the French architectural landscape, of which farmsteads formed an essential part. ${ }^{29}$

Swedish and Finnish agritectural reformers promoted not only the printing of plans for improved farm buildings but also their distribution to the peasantry at low or even no cost. These endeavors culminated in several ambitious projects of the late 1850s and the 1860s. For example, in 1859, the architect Adolf Wilhelm Edelsvärd submitted a proposal to the assembled representatives of Swedish estates concerning measures for enhancing the quality of rural architecture. $\mathrm{He}$ urged the establishment of official regulations and supervision and the publication of a series of drawings for farmers of little means. Edelsvärd argued that these plans should be lithographed at government expense, distributed in every school in Sweden for easy consultation by local peasants, sold at affordable prices, and revised regularly to meet constantly changing needs. The committee assigned to evaluate
Edelsvärd's proposal agreed that the quality of rural architecture was of utmost national importance, because it represented "the strength, the state of development, and the level of civilization of a nation. ${ }^{30}$ Nevertheless, the proposal was rejected, one of the justifications being that circumstances varied too widely from one region to another for a single set of designs to be practical. ${ }^{31}$

That same year, two architectural competitions were organized to solicit plans for farm buildings, one by the Swedish Agricultural Academy and the other by the Uusimaa and Häme Provincial Agricultural Society in Finland. Neither of these competitions attracted any architects, however, possibly because of the scant cash prizes offered. ${ }^{32}$ In 1862, the Provincial Agricultural Society sponsored a competition that offered more valuable prizes, and four entries were received. This competition's organizing committee stressed that the cost of "an ordinary Finnish peasant's farmstead" should not be higher than usual and that the ornamentation should be simple. ${ }^{33}$ The ultimate aim of the competition, deemed by 


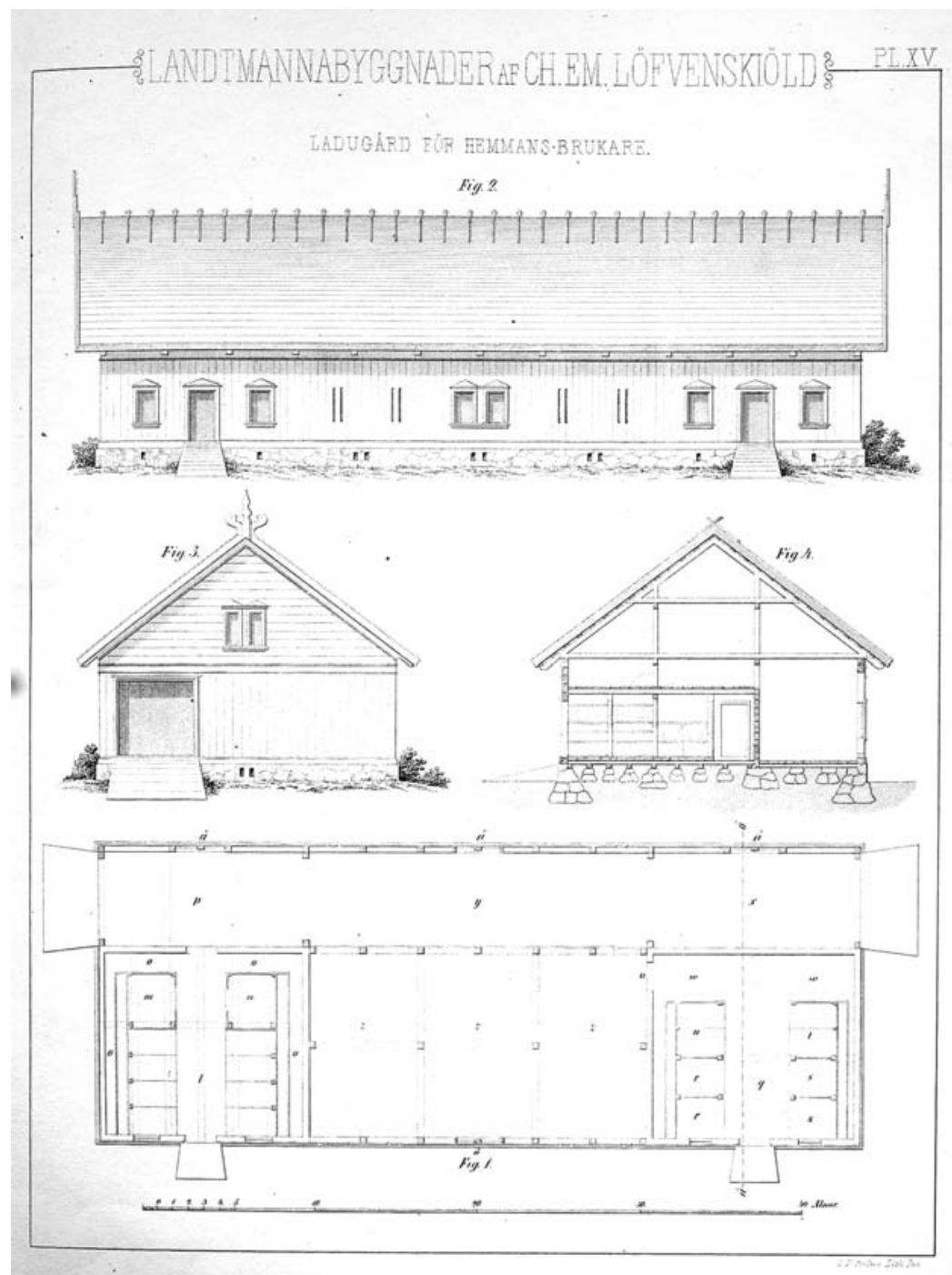

Figure 4 Charles Emil Löfvenskiöld, outbuilding for a farmstead, 1854 (C. E. Löfvenskiöld, Landtmanna-byggnader [Stockholm: C. A. Forselius, 1854]; Museum of Finnish Architecture).

the Finnish Senate to be of utmost utility and national importance, was to encourage the printing of plans with bilingual explanations - in Swedish and Finnish—so as to ensure broad readership. The printing of the resulting plans was financed in part by the state, and the plans were distributed free of charge to the roughly one hundred peasant members of the Provincial Agricultural Society. ${ }^{34}$

The governing board of the society, composed of gentlemen farmers and owners of large estates, awarded the first prize to Georg Theodor Chiewitz, a Swedish architect and civil engineer who had lived and worked in Finland since the early 1850s. ${ }^{35}$ His winning series of drawings included a farmhouse with several outbuildings and a sauna (Figure 5). The various structures were situated symmetrically around a yard, with trees lining curved drives (Figure 6). Apart from symmetry and order, Chiewitz devoted special attention to ventilation, mechanical feeding of animals, and efficient drainage to facilitate the production of fertilizers. The farmhouse was a two-story timber structure with battenboard cladding on the upper part of the gable end. This cladding was decorated with holes cut in cross patterns, its lower edges forming a scallop pattern across the top and center of the façade. Further embellishment of this large farmhouse included an overhanging roof supported by brackets, a carved bargeboard under the eaves, two tall chimneys, and a finial at the gable's peak.

Well received by Swedish-language journals in Finland, Chiewitz's plans were seen by some as a viable solution to the perceived lack of comfort, beauty, taste, and order in Finnish rural architecture. ${ }^{36}$ The plans appear to have been entirely ignored by the Finnish-language press, however, probably because Chiewitz's unusual floor plan and use of ornament were regarded as unsuitable for peasants of modest means. The aim of the Provincial Agricultural Society had been to publish plans for "an ordinary Finnish peasant's farmstead," but the winning entry's ideal peasant was untypically wealthy, 


\section{MANBYGGNAD. ASUINRAKENNUS.}

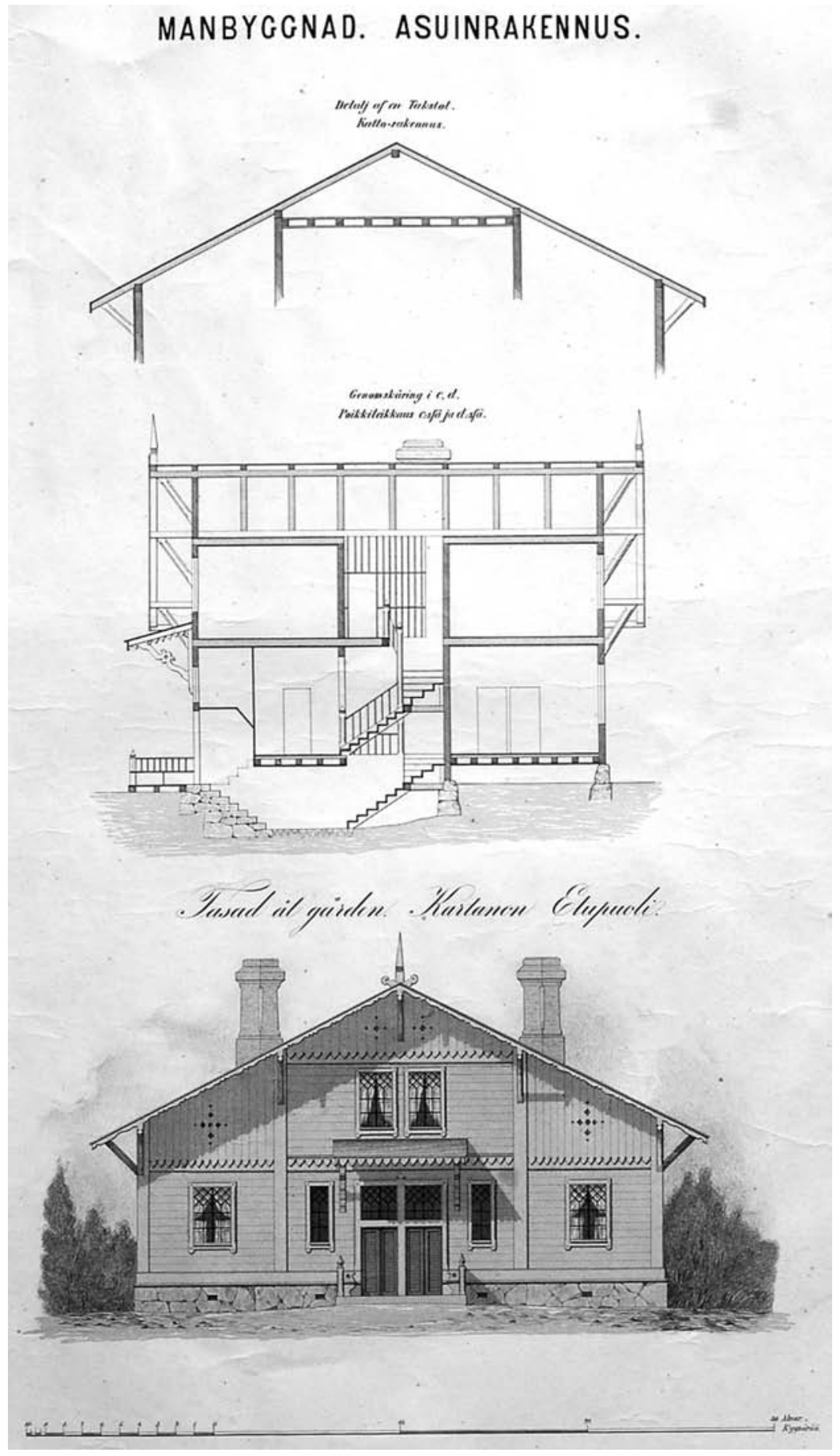

Figure 5 Georg Theodor Chiewitz, plan for a Finnish peasant farmhouse, 1862 (Museum of Finnish Architecture).

manner of building; it included almost no decorative elements (Figure 7). The brief accompanying text ("This plan is added, because if one wishes to follow it, he is allowed to do so") suggests that while not preferred by the jury, Trapp's plan may have been deemed preferable by more traditionally minded farmhouse occupants. ${ }^{38}$ The side-by-side publication of Chiewitz's and Trapp's plans indicates that the reformers were fully aware of the challenges of changing the habits of peasant builders. They offered traditional alternatives while advocating more modern, more decorative options. 


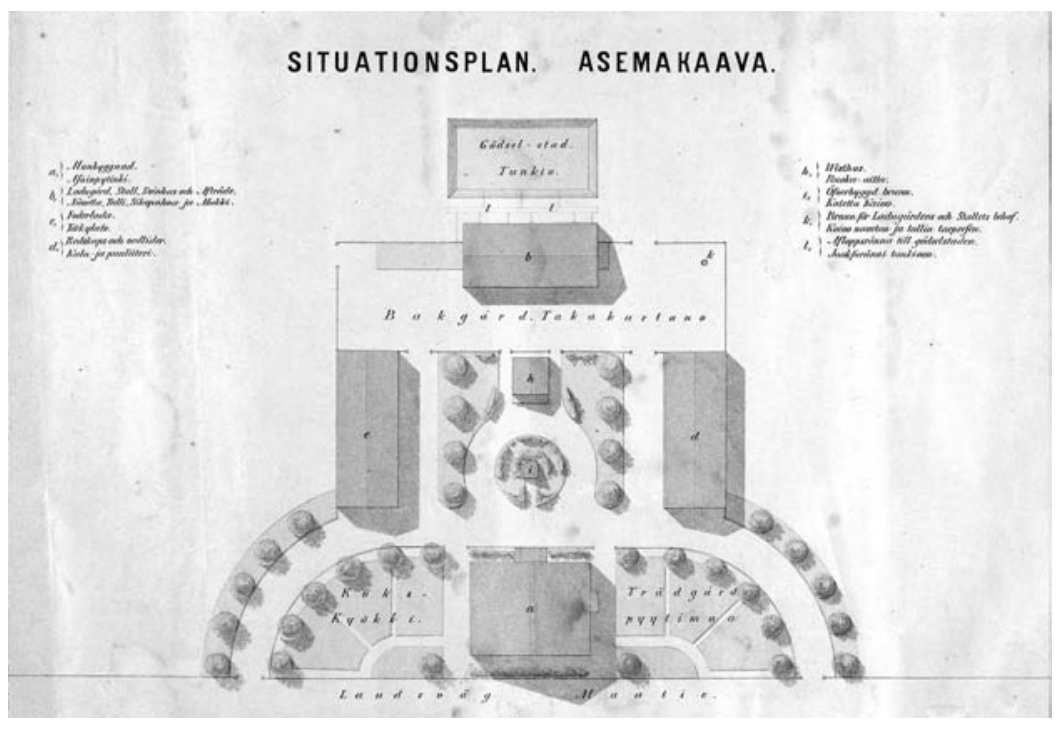

ก. . .

ITKLST TILI. BONINGSHIS A ETT FINSKT BONDHEMMAN.

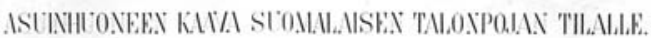
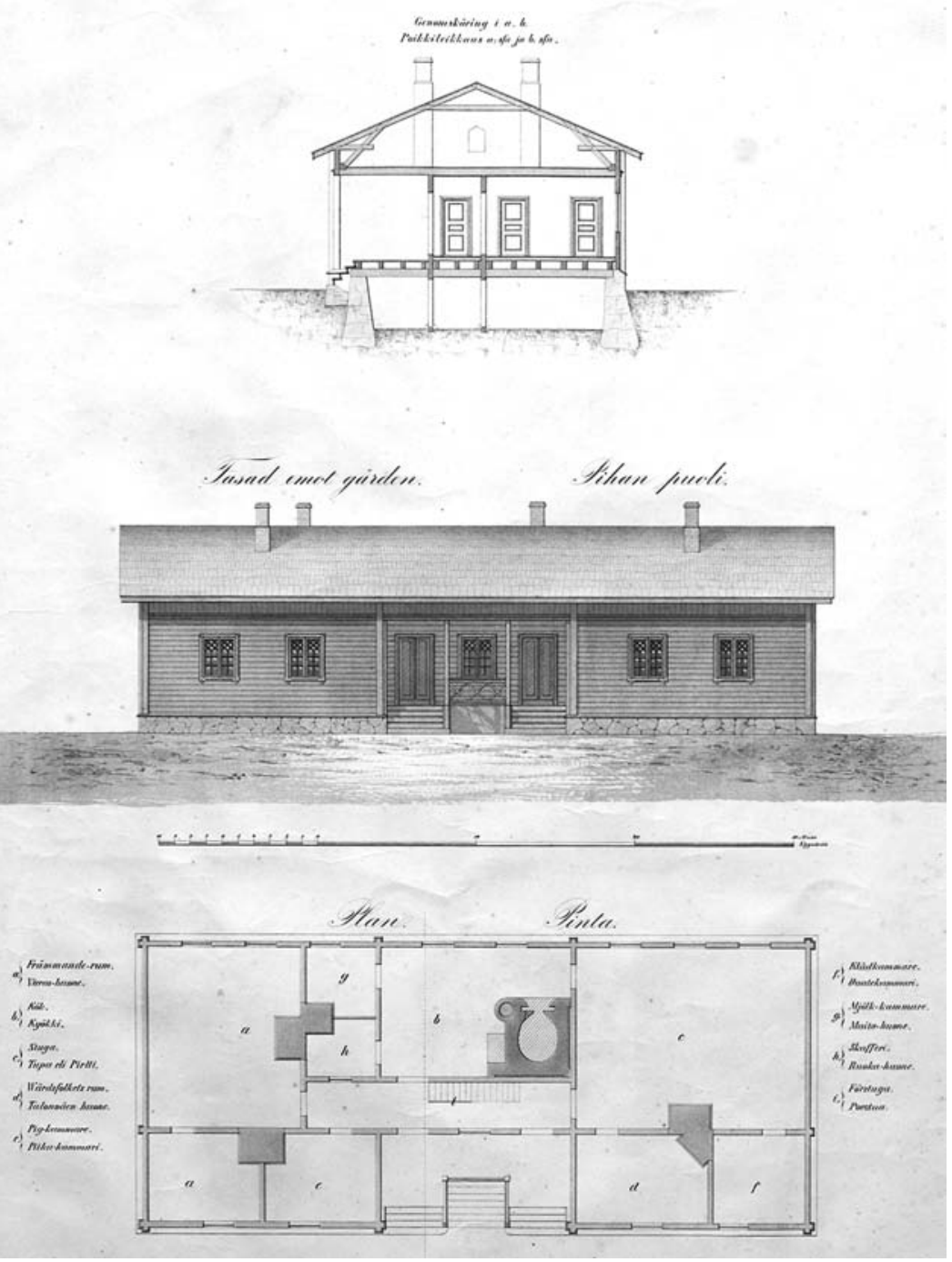

Figure 6 Georg Theodor Chiewitz, site plan for a Finnish peasant farmstead, 1862 (Museum of Finnish Architecture).

Figure 7 Hugo Trapp, plan for a Finnish peasant farmhouse, 1862 (Museum of Finnish Architecture) 


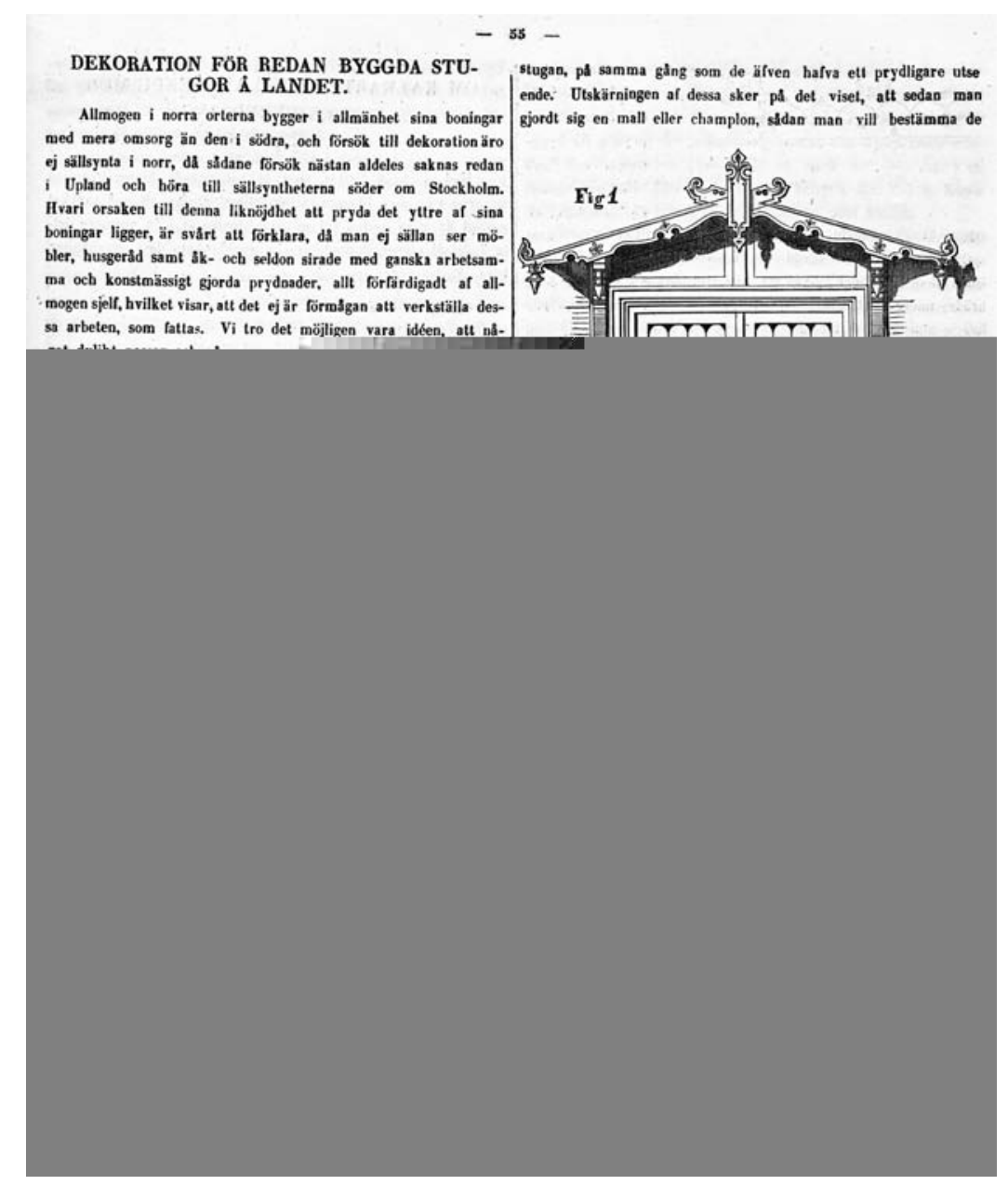

Figure 8 Suggested decorations for rural buildings, 1850 ("Dekoration för redan byggda stugor å landet," Tidskrift för praktisk byggnadskonst och mekanik m.m. 1 [1850]; National Library of Sweden).

\section{The Utility of Ornament}

Here and elsewhere, decoration was seen as key to the modernization process. In the mid-nineteenth century, a plethora of articles promoting the use of wood carvings in farm buildings were published in Swedish magazines. In 1850, the editors of $7 P A M$ suggested that existing timber structures in the Swedish countryside could be substantially improved through the addition of new decorations. According to the journal, Swedish people were capable of high-level craft, as their finely decorated wood furniture attested, but for some unknown reason rural people, especially in southern Sweden, were disinterested in decorating the exteriors of their buildings. To help rectify this situation, the journal provided plans and detailed instructions for carving appropriate wooden ornaments (Figure 8). The editors claimed that "anyone accustomed to using a plane, a saw and a splendid Swedish knife" could easily execute the designs. They suggested that farmhands could craft the embellishments during long winter nights, while they had no other useful occupation. The amount of wood needed would be small and, even more important, would cost the peasant little or nothing. ${ }^{39}$
The usual argument in favor of architectural ornament on farm buildings was that the manufacture of such ornament would occupy landless agricultural workers in a morally upright way. Elite reformers assumed that rural laborers would otherwise waste their free time on drinking, gambling, and other "immoral" behaviors. Many Scandinavian farmers distilled spirits at home, both for their own consumption and as a way of earning extra money. Attacking this established custom, numerous educational publications pointed to the harmful effects of alcohol on both rural people and agricultural productivity. Handicraft and other subsidiary industries were encouraged as morally improving alternative practices. ${ }^{40}$ The same themes were circulating in other places. As early as 1828, the Frenchman Baron Dupin had insisted that some form of industrial activity must be introduced into every agricultural community in order to occupy rural laborers and keep them from immoral behavior during those times when they were not performing their farming duties. ${ }^{41}$

While craft work was widely considered to be beneficial for rural laborers, many nineteenth-century writers nonetheless emphasized the inappropriateness of ornamentation 



Figure 11 Charles Emil Löfvenskiöld, piggery, 1854 (C. E. Löfvenskiöld, Landtmanna-byggnader [Stockholm: C. A. Forselius, 1854]; Museum of Finnish Architecture).

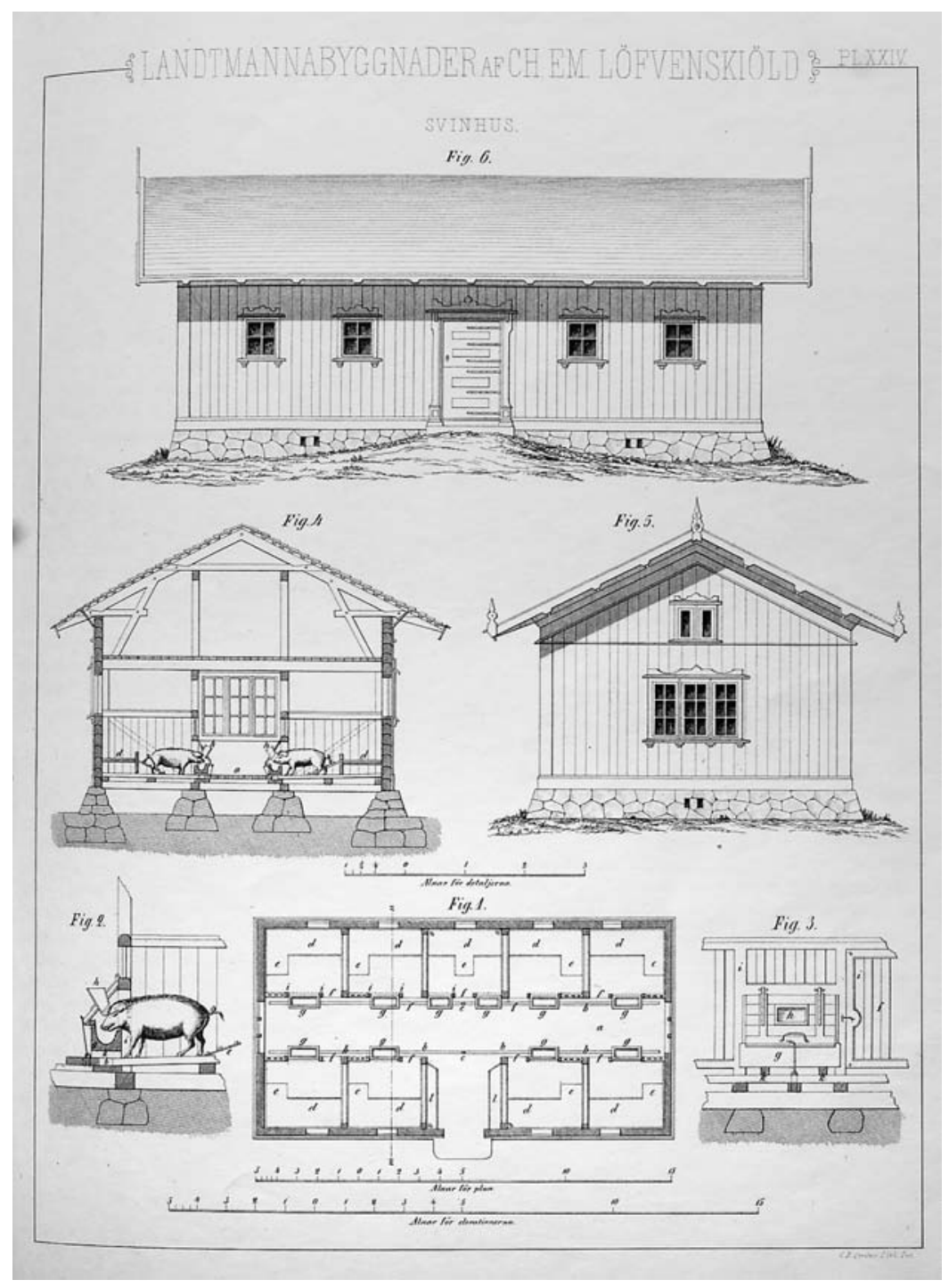

modern rail feeder in his well-ventilated barn as well as a system of subterranean drains, pumps, and reservoirs for the capture and storage of manure, which could be used as fertilizer (Figure 12). Sundius called his cattle barn "a milk and fertilizer factory"; in doing so, he linked cows to both machines and their fuel. Yet he acknowledged that cows were also living, emotional beings who felt joy and suffering much as did humans. Accordingly, they deserved rest, fresh air, sunlight, and all things necessary for a good life in compensation for the nourishment and pleasure they provided to humans. ${ }^{66} \mathrm{In}$ encouraging an emotional attachment between humans and animals, Sundius hoped to foster a culture of care that would extend to the broader built and natural environments.

Wooden architectural ornament could also contribute to this culture of care. Reformers deemed wood handicraft beneficial for rural society in multiple ways. Craft was promoted as an activity that was both creative and physical, connecting the carver's mind and body to the materiality of wood.
Encouraging the use of ornament in poor peasants' buildings, Sundius argued that if peasants devoted some winter nights to making decorations for their farm buildings, they would become more emotionally attached to those buildings. ${ }^{67} \mathrm{Re}-$ formers assumed that the efforts and thoughts of the peasant carver would be incorporated into each object by the act of its making, creating an indelible bond between the carver and the work. Even a small investment in ornamentation would lead to improvements in the built environment and agricultural productivity, as well as in the ongoing maintenance of buildings. In Edelsvärd's mind, "the crowning, standing ornaments" placed on eaves and openings, especially, required regular upkeep: if the homeowner was not willing to keep them in good shape, it was better not to use them at all. ${ }^{68}$ Therefore, by urging peasants toward good housekeeping, architectural ornament served as a vehicle for order and emotional well-being in Scandinavian rural society writ large. 


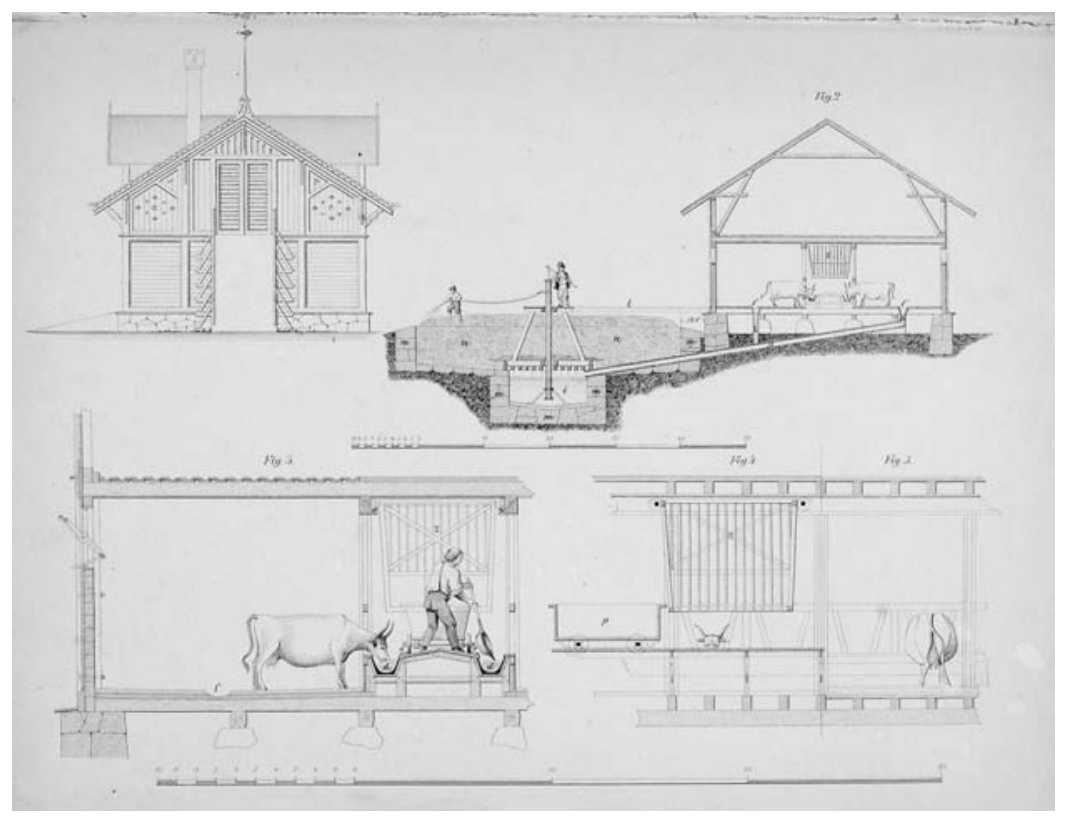

Figure 12 Petter Georg Sundius, cattle barn, 1858-59 (P. G. Sundius, Landtbruks-arkitektur: En samling af till en del redan utförde byggnader på landet [Stockholm: J. Theod. Bergelin, 1858-59]; Museum of Finnish Architecture).
Detailed instructions on how to make architectural ornaments from wood were published in many Swedish magazines (Figure 13). Some included full-scale drawings to demonstrate best practices for sawing and carving (Figure 14). ${ }^{69}$ Illustrations drew on imagery circulating in contemporary architectural publications, particularly journals and pattern books of the German-speaking world. One widely used source was Ludwig Degen's Motive zu ornamentalen Zimmerwerken, published in 1857 (Figure 15). ${ }^{70}$ Several Swedish architects followed Degen's model, offering variations on his decorations that fused elements from many historical periods and sources-classical, medieval, vernacular. ${ }^{71}$ These Nordic decorations, such as the ones by Löfvenskiöld, were simplified versions of Degen's and other German models, all indicative of a deep and widespread interest in ornament and its potential to affect the modern mind.

Nordic reformers wrote little about their preferred forms for wood ornament. Instead, they focused on materiality, crafting processes, and, particularly, the presumed aesthetic, moral, and societal benefits of these elements. In doing so, they often conflated ornament and its objects. As Alina Payne has demonstrated, mid-nineteenth-century design was marked by a gradual shift from "the explicating and rhetorical function traditionally shouldered by ornament to the objects

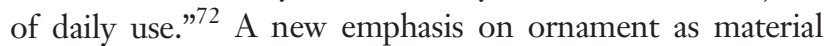
culture (Sachkultur) gave it meaning and relevance only in relation to the objects it decorated. ${ }^{73}$ Nordic wood farm decorations were exemplary of this objectification, wherein ornament and object were equalized and, ultimately, merged.

Reinterpreting and simplifying continental models, Swedish architects offered a range of floral and abstract geometrical motifs. These were meant to provide starting points for peasant craftsmen, who were expected to imitate or modify the designs to their liking; at the same time, strict limits were imposed on invention. Löfvenskiöld encouraged experienced woodworkers to alter the forms provided and to create their own designs, yet he stressed that a farmstead, including any ornament, must be aesthetically unified. ${ }^{74}$ Fostering creativity within the confines of an aesthetic ideal, Löfvenskiöld and his ilk were at the threshold of an emerging practice. They offered compendiums, collections of motifs from which users could choose the most suitable forms for their purposes or develop their own within limited frameworks. ${ }^{75}$ The model ornaments in published pattern guides were intended to educate and uplift skillful and decent laborers.

Like their counterparts elsewhere, Nordic reformers emphasized the moral virtue of handicraft and its potential as an agent for social progress. Löfvenskiöld and others promoted craft, home industry, and moral education in all sectors of rural life. The Swedish Society of Handicraft (Svenska Slöjdföreningen), founded in 1845 , sought not only to increase local production and use of craft goods-in the face of rising imports of manufactured goods-but also to nurture native intelligence and skill, and to highlight the belief that "order, simplicity, and thrift in home life were the necessary prerequisites for comfort, independence and improvement." ${ }^{\text {"76 }}$ Yet the Scandinavian reform movement differed from similar movements in more industrialized countries such as England, where mechanical production and handmade crafts were often seen as being in conflict. In the Nordic countries, craft promotion was closely linked to the promotion of manufacturing in general, and it was ultimately thought to matter little whether items were produced by hand or by machine. Promoters of architectural ornament encouraged the 
Figure 13 Charles Emil Löfvenskiöld, wood carvings for farm buildings, 1868 (C. E. Löfvenskiöld, Landtmannabyggnader hufvudsakligen för mindre jordbruk [Stockholm: P. A. Norstedt \& Söner, 1868]; Museum of Finnish Architecture).

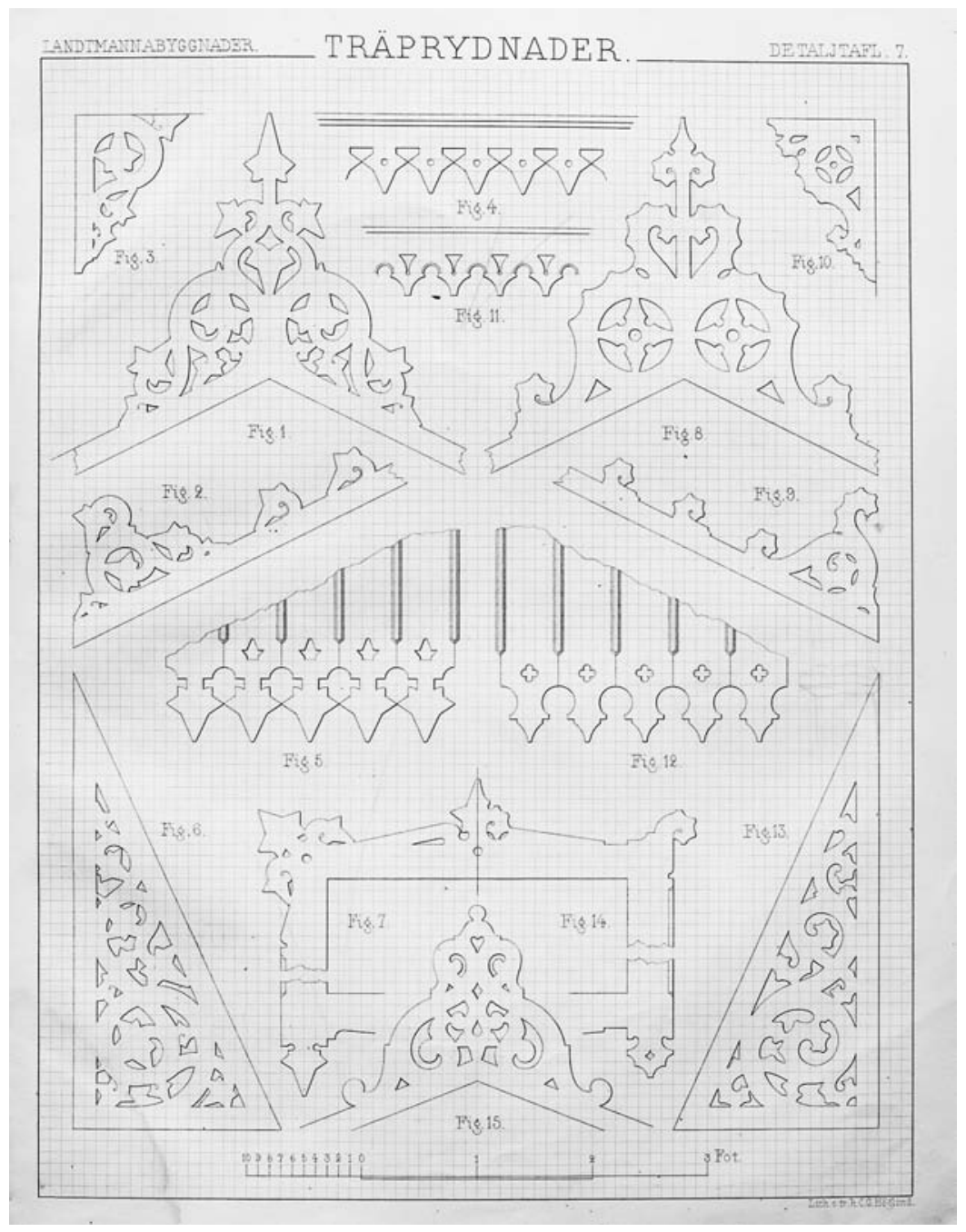

display of both handmade and machine-made products. ${ }^{77}$ The carving knife remained the most important tool for woodworkers, but reformers also recommended the domestic use of mechanical saws and other modern tools. As Löfvenskiöld wrote, the saw was both easy to use and cheap to buy. ${ }^{78}$ Although farmers could commission mechanically produced wood carvings from manufactories in Stockholm and Gothenburg, their use of their own "time was less expensive." As Edelsvärd suggested, rural craftsmen could easily make decorations during the long winter nights, preferably with pedalor crank-driven saws. ${ }^{79}$ Nordic reformers saw in handicraft and related occupations a pragmatic solution for the growing problem of rural underemployment. In 1846, an anonymous writer in a progressive Finnish journal stated that "it would be highly desirable if the landless, in particular" were to start producing handicrafts or otherwise devoting themselves to industry, "through which their economy could be considerably improved." Further, he claimed:

Encouraging household craft is one of the most powerful tools to eradicate begging and immorality; because diligence and constant activity brings well-being and decency. Those who buy handicrafts and thus encourage craft do a great favor for their country. For sure, there is less poverty and vagrancy in those parishes in which the poor have an opportunity to earn their living by work. ${ }^{80}$

The benefits to be derived from freedom of industry and trade were being hotly debated at this time in Swedish and Finnish newspapers and other publications. "Handicraft and the freedom of industry are the foundations of well-being," declared an anonymous Finnish writer in 1847. He deplored the fact that, because of the long Nordic winters, agricultural laborers had no steady employment for much of the year. These conditions favored the production of handcrafted household goods of all kinds, but, as already noted, laws were in place that prohibited rural laborers from manufacturing goods for profit. The writer advocated the abolition of these outdated laws and urged landowning farmers to support the poor by establishing craft workshops on their farmsteads. By providing agricultural work and craft industry (the former in 


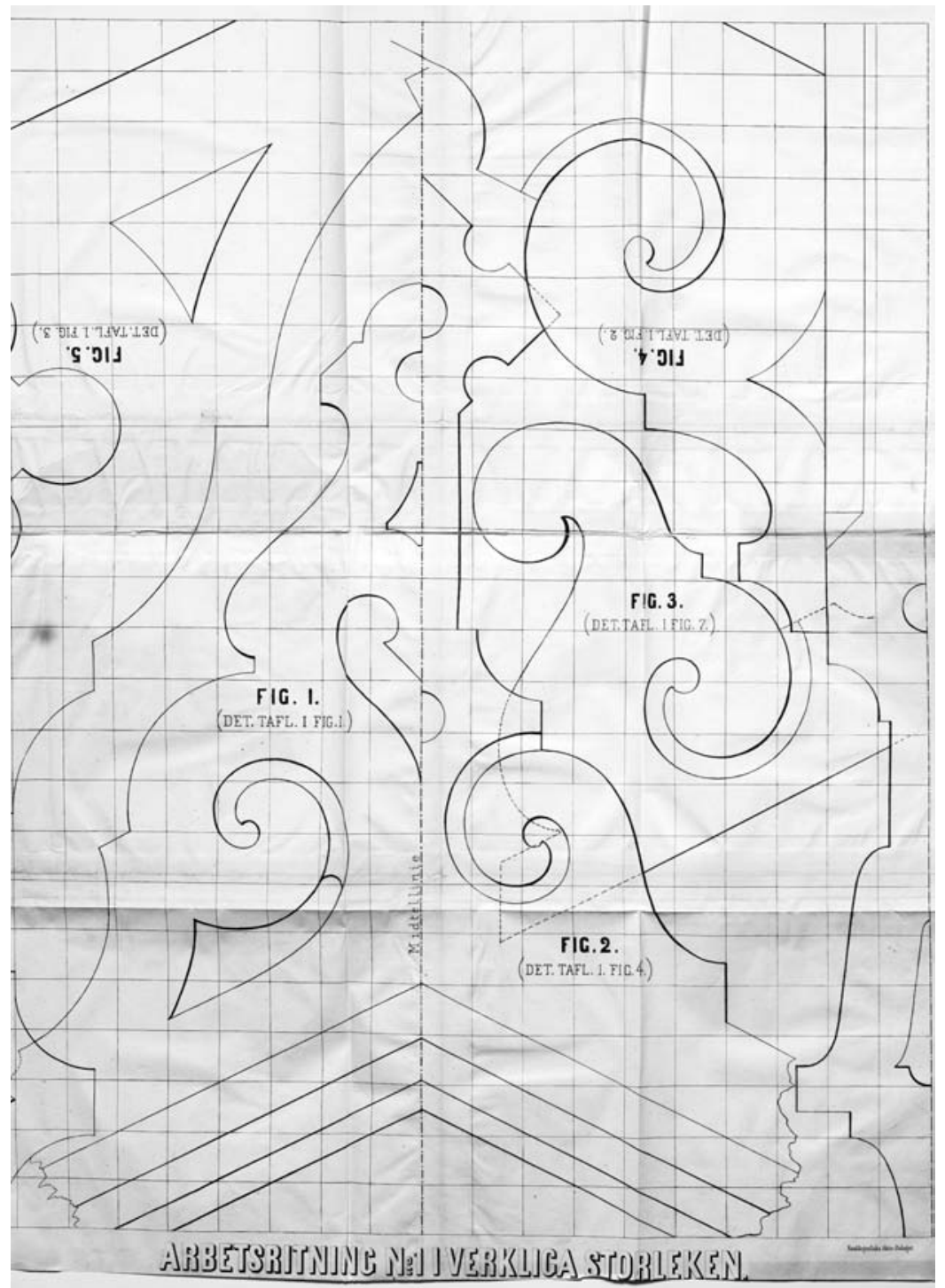

Figure 14 Charles Emil Löfvenskiöld, full-scale plans for wood carvings, 1868 (C. E. Löfvenskiöld, Landtmannabyggnader hufvudsakligen för mindre jordbruk [Stockholm: P. A. Norstedt \& Söner, 1868]; Museum of Finnish Architecture). summer, the latter in winter), the patrons would have laborers at their disposal year-round. This, the writer argued, would be beneficial for everyone. ${ }^{81}$

\section{Imagining Modern Scandinavia}

Most of the Swedish-language agritectural publications of the mid-nineteenth century were distributed in both Sweden and Finland, where Swedish architects like Chiewitz and Sundius worked in the 1850s, and where the language of gentlemen farmers was Swedish. These publications promoted the idea of a unified Scandinavian sphere across national borders, one with its own distinctive unitary culture, language, and architecture. One objective of the reformers was to express through architecture their ideal of the Nordic peasant, whom they believed to be humble, civilized, efficient, and skillful in both farming and craft work. The modern farm architecture they envisioned was meant to create a positive image of
Scandinavia and its people, one characterized by moderation and plain beauty.

Reformers believed that wood carving, an essential part of their pan-Scandinavian architectural ideal, was central to their project of regenerating rural society. Through standardized plans and architectural wood carvings, the archaic local building "type" - the poor peasant's hut—could be developed, embellished, elevated, and made suitable for modern needs. ${ }^{82}$ Improving the Scandinavian rural built environment—which most reformers deemed largely deplorable—with ornamentation originating in German publications meant connecting the remote countryside to the broader realm of Western civilization. These decorations were viewed as part of a shared European heritage, objects whose use would help bring together the "civilized" world. ${ }^{83}$

The ultimate aim of these liberal reformers, who promoted freedom of industry and welfare for every social class, was a well-ordered rural environment that made significant, 
Figure 15 Louis (Ludwig) Degen, gable ornament, 1860 (Louis Degen, Motifs de décoration et d'ornement des constructions en bois [Paris: A Morel, 1860]; Bibliothèque de I'Institut National d'Histoire de l'Art, Collections Jacques Doucet, 4 GT 1619).

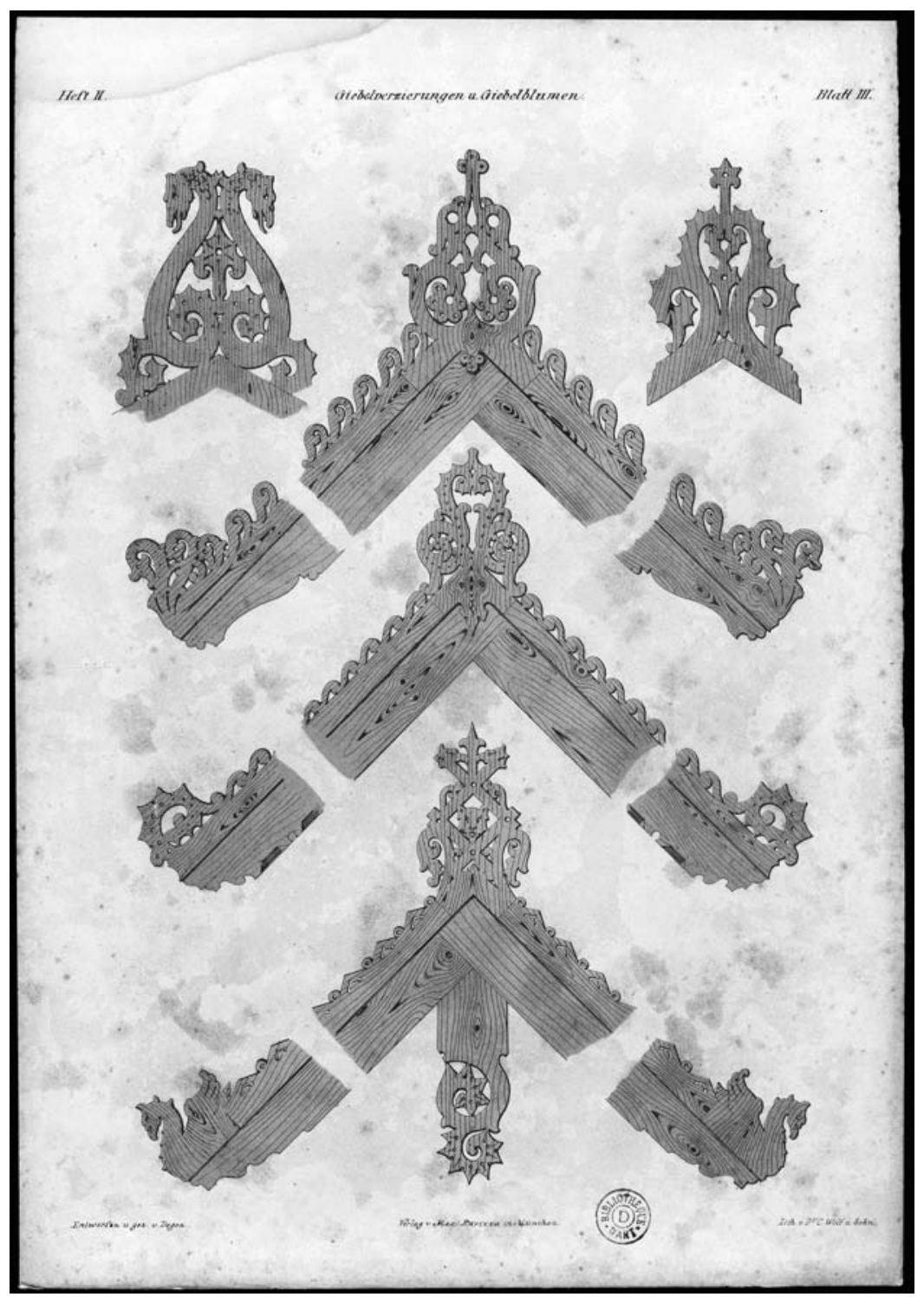

and comfort it would bring. ... Who could not wish, from the bottom of his heart, for this future for the fatherland ${ }^{86}$

The effort to reform local building traditions through modern farm designs was ambitious, and it was not successful on all counts. Although aimed at peasants living throughout Sweden and Finland, the project's core literature reached only the upper strata of agrarian societygentlemen farmers and owners of large estates. In fact, the landless may have encountered the new ideas only while working on manorial estates. ${ }^{87}$ Nevertheless, in the long run, the movement contributed significantly to reforms in farm planning - in Sweden, at least. There, the use of wood carvings became widespread, especially on the most affluent farmsteads. ${ }^{88}$

In Finland, agritectural reform reached only a small number of farmsteads during the mid-nineteenth century, 


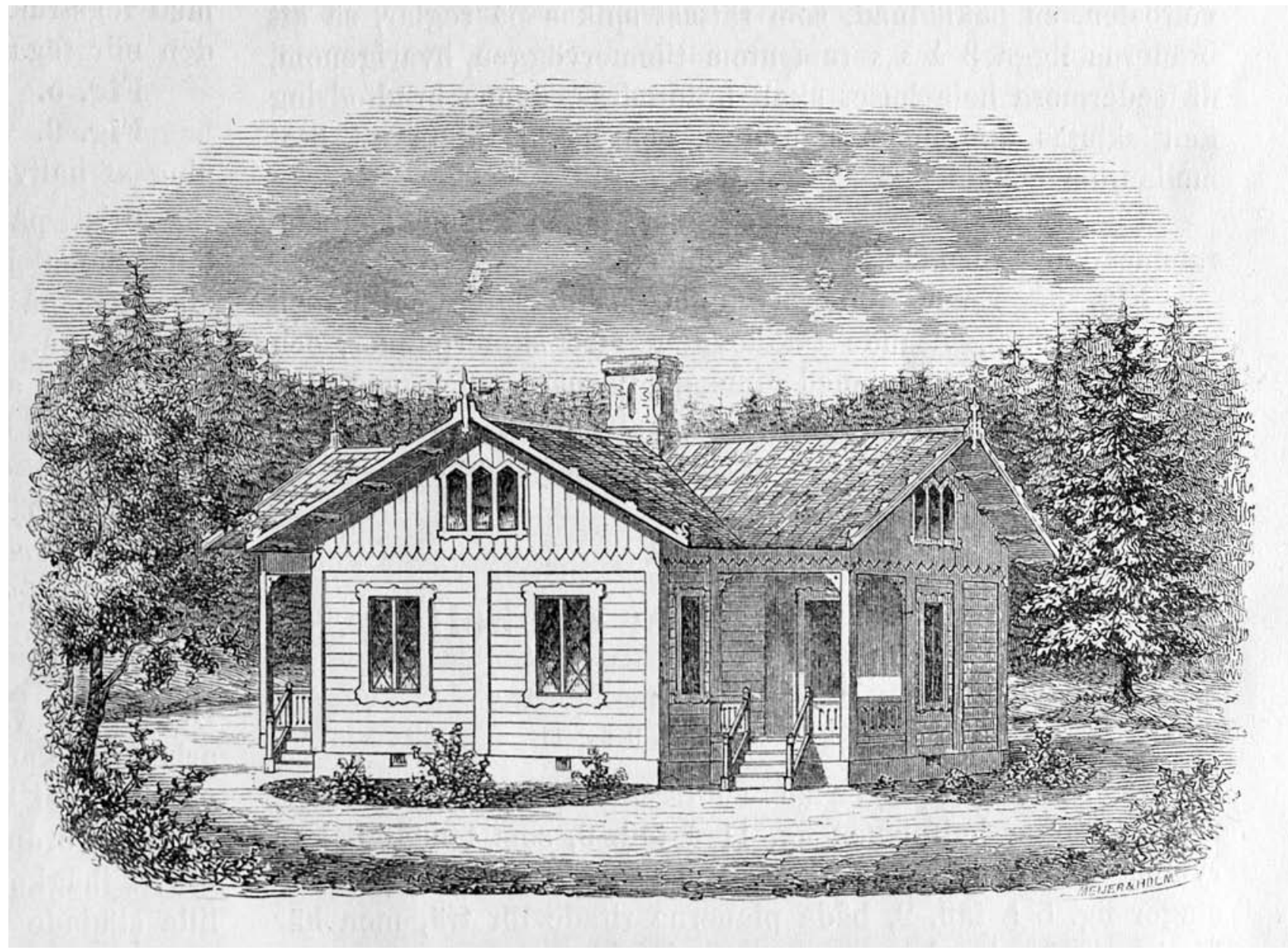

Figure 16 Adolf Wilhelm Edelsvärd, two-family farmhouse for tenant farmers or rural laborers, 1868 (C. E. Löfvenskiöld, Landtmannabyggnader hufvudsakligen för mindre jordbruk [Stockholm: P. A. Norstedt \& Söner, 1868]; Museum of Finnish Architecture).

and those were almost exclusively prosperous and progressive manorial estates. The circulation and impact of plans published by the Uusimaa and Häme Provincial Agricultural Society, in particular, remained limited. ${ }^{89}$ By and large, Finnish peasants and rural laborers did not embrace the use of published plans and carved wooden ornament; traditional building methods persisted among those groups well into the next century. Even so, this period saw the emergence of a genuine interest in local ornamental traditions. In the 1840 s, one anonymous writer praised the traditional ornamentation found on old peasant buildings in eastern Finland and recommended its use in modern buildings. According to this author, traditional decorations were a cultural treasure, "inherited from our fathers, just like our cultivated land, our language, and customs." ${ }^{90}$ It was not until some decades later, however, that architects started to study local traditional architecture and Sachkultur, which by the 1890 s became a source of inspiration for the young national romantic generation of artists, architects, composers, writers, and others. ${ }^{91}$

\section{Agritecture, Ornament, and Politics}

In the mid-nineteenth century, a range of Swedish-language publications disseminated an ideology of reform, progress, and welfare throughout the Scandinavian countryside. In their discussions of architectural ornament, reformers outlined aesthetic and political agendas with broad implications for the future of Scandinavian rural societies. They advocated the use of wood carvings in farm buildings, asserting that the creation of such ornament could bring about substantial benefits-not least, an increase in agricultural productivity and the provision of employment and extra income for rural laborers during long northern winters. Before the rise of a modern forest industry later in the nineteenth century, the production of handicraft was widely regarded as a key to prosperity in rural areas. Wood carvings would elevate humble farm buildings and the people who occupied them, radiating well-being into the surrounding countryside. Requiring skill and good taste from the craftsmen and the constant care of the farmers who owned them, reformed buildings and their decorative embellishments would be morally uplifting, 
and thus genuinely useful components in the construction of an ideal modern society.

Despite some success, the mid-nineteenth-century reform efforts discussed here could not prevent the severe agricultural crisis that hit both Sweden and Finland in the 1860s. Following several years of crop failures, famine became widespread, especially in Finland, where it resulted in the deaths of almost 10 percent of the national population in 1867-68. Most of these deaths were concentrated in the countryside. Once again, the modernization of agriculture became an urgent political issue.

The agritectural reform movement of the mid-nineteenth century had aimed to bring order to an environment and society that reformers saw as chaotic and in crisis. They believed that carved wooden ornamentation would complete and correct both the Scandinavian built environment and Scandinavian society as a whole. ${ }^{92}$ Architectural ornament became the frame for an envisioned ideal future society-sometimes quite literally (see Figure 2). Although they might appear insignificant to modern eyes, the details that these reformers inscribed onto the roofs, windows, and doorways of their model buildings signified well-being and civilization as defined by the Swedish cultural elite, a definition they hoped would extend its influence across the Scandinavian countryside.

Anna Ripatti is an art and architectural historian whose research has focused mainly on Nordic architecture, historic preservation, and historiography in the long nineteenth century. Her new project explores architectural standardization in mid-nineteenthcentury France. anna.ripatti@helsinki.fi

\section{Notes}

1. This article is a part of my postdoctoral research project, supported by the Kone Foundation. My deepest gratitude goes to the following persons: Nina Aspinen, Matthew Growhoski, Martha Howell, Rainer Knapas, Ville Lukkarinen, Riitta Nikula, Markku Peltonen, and my colleagues at the Finnish Literature Society, where I conducted most of the research. I would also like to thank the anonymous reader and $7 S A H$ editor Keith Eggener for their helpful comments and refinements, and the wonderful librarians and other staff at the Museum of Finnish Architecture, the National Library of Sweden, and the Royal Swedish Academy of Agriculture and Forestry for their invaluable assistance.

2. I use the term Scandinavia in its nineteenth-century sense, which is synonymous with the so-called Nordic countries: Sweden, Norway, Denmark, and Finland. In the middle of the nineteenth century, use of the term was encouraged by proponents of "Scandinavianism," a cultural and political movement that cherished the idea of a united Scandinavia. Finland is now often excluded from "Scandinavia," but historically and culturally it was seen as part of that region. See Kari Haarder Ekman, "Mitt hems gränser vidgades": En studie i den kulturella skandinavismen under 1800-talet (Gothenburg: Makadam Förlag, 2010), 11.

3. Historical Statistics of Sweden 1: Population 1720-1967, 2nd ed. (Stockholm: National Central Bureau of Statistics, 1969), tables 3, 22, and 23; Carl-Johan Gadd, "The Agricultural Revolution in Sweden," in Agrarian History of
Sweden: From 4000 BC to AD 2000, ed. Janken Myrdal and Mats Morell (Lund: Nordic Academic Press, 2011), 133; Viljo Rasila, "Suomalainen yhteiskunta 1865," in Suomen maatalouden bistoria 1, ed. Viljo Rasila, Eino Jutikkala, and Anneli Mäkelä-Alitalo (Helsinki: Finnish Literature Society, 2003), 451.

4. C. E. Löfvenskiöld, "Några ord om landtbyggnadskonstens utveckling i landet under de sista 30 åren," Kungl. Landtbruks-Akademiens Tidskrift, no. 3 (1869), 132, my translation. Unless otherwise noted, all translations are my own.

5. On Löfvenskiöld, see Catharina Svala, Lantbruksarkitekten Charles Emil Löfvenskiöld 1810-1888 (Alnarp: Sveriges Lantbruksuniversitet, 1990); Catharina Svala, "Charles Emil Löfvenskiöld: Lantbruksarkitekturens nydanare," in Svenska bus: Landsbygdens arkitektur-från bondesambälle till industrialism, ed. Thomas Hall and Katarina Dunér (Stockholm: Carlssons, 1995), 66-69; Ulrich Lange, "Den svenska lantbyggnadskonstens fader: Charles Emile Löfvenskiöld och fähusarkitekturen,” Bebyggelsehistorisk tidskrift, no. 29 (1995), 75-82; Ulrich Lange, Ladugairden: Om lantbrukets bebyggelse och arkitektur 1600-2000 (Stockholm: Nordiska Museet, 2011), 115-17; Siegrun Fernlund, " "The Demands of the New Age': Ideology and Practice in Building Activity on Scanian Estates in the Nineteenth Century," in Modernisation and Tradition: European Local and Manorial Societies 1500-1900, ed. Kerstin Sundberg, Tomas Germundsson, and Kjell Hansen (Lund: Nordic Academic Press, 2004), 278-79.

6. See Erik Nordin, Träbyggande under 1800-talet: Debatt och verklighet (Stockholm: Civiltryck, 1972); Ann Katrin Pihl Atmer, Sommarnöjet i skärgården: Sommarbebyggelse i Stockholms inre skärgaird 1860-1915 (Stockholm: Kommittén för Stockholmforskning, 1987); Jens Christian Eldal, Historisme i tre: "Sveitserstil," romantikk, byggesskikks-renessanse og nasjonal egenart i europeisk og norsk trearkitektur på 1800-tallet (Oslo: Oslo Universitet, 1996); Mari Hvattum, "Panoramas of Style: Railway Architecture in Nineteenth-century Norway," FSAH 70, no. 2 (June 2011), 190-209; Mari Hvattum, Heinrich Ernst Schirmer: Kosmopolittenes arkitekt (Oslo: Pax Förlag, 2014), 115-35.

7. See Joseph Bizup, Manufacturing Culture: Vindications of Early Victorian Industry (Charlottesville: University of Virginia Press, 2003); Valérie Nègre, L'Ornement en série: Arcbitecture, terre cuite et carton-pierre (Sprimont, Belgium: Pierre Mardaga, 2006); Paul Dobraszczyk, Iron, Ornament and Architecture in Victorian Britain: Myth and Modernity, Excess and Enchantment (Farnham, England: Ashgate, 2014).

8. Carl-Johan Gadd, Det svenska jordbrukets historia 3 (Stockholm: Nordiska Museet, 2002); Juhani Saarenheimo, "Isojako," in Rasila et al., Suomen maatalouden historia 1, 349-64; Teppo Korhonen, "Koneiden aika alkamassa," in Rasila et al., Suomen maatalouden bistoria 1, 461-63.

9. In nineteenth-century Sweden and Finland, a peasant (in Swedish bonde, in Finnish talonpoika) was a farmer who occupied an officially registered homestead (in Swedish bemman, in Finnish maatila), either as a landowner or as a tenant on land owned by the state or the nobility. Having both high social and economic status and political standing as one of the four estates represented in the Diet, Nordic peasants formed a specific social class, distinct from noble gentlemen farmers and landless agricultural workers. I use the term peasant here to refer to this class. See Gadd, "Agricultural Revolution in Sweden," 122.

10. See Gadd, "Agricultural Revolution in Sweden”; Pekka Haatanen, Suomen maalaisköybälistö tutkimusten ja kaunokirjallisuuden valossa (Porvoo: Werner Söderström Osakeyhtiö, 1968).

11. In Sweden, especially in the region of Svealand, the mining industry and charcoal burning provided extra income for rural inhabitants. Gadd, "Agricultural Revolution in Sweden," 120.

12. Gadd, 138; Eino Jutikkala, Suomen talonpojan bistoria (Porvoo: Werner Söderström Osakeyhtiö, 1942), 522, 552-56.

13. See "Förslag emot Pauperismen," Teknologen, no. 19 (9 May 1846), 161. 14. Haatanen, Suomen maalaisköybälistö, 60-65. 
15. On the first Swedish and Finnish agricultural fairs, see Olof Kåhström, ed., När landet kom till staden: Lantbruksmöterna och lantbruksutstälningar som arenor för agrara moderniseringssträvanden $i$ Sverige och Finland 1844-1970 (Stockholm: Kungl. Skogs- och Lantbruksakademien, 2013). Mid-nineteenth-century Scandinavian agricultural magazines included Tidskrift för Landtmanna- och Kommunalekonomien (1840-61), Lukemisia Maamiebille (1849-51), Suomen Huoneenballitusseuran Sanomia (1851-53), Tidskrift för landtbushällare (1854-57), and Tidskrift för Svenska Landtbruket och dess Binäringar (1855-64).

16. Haatanen, Suomen maalaisköybälistö, 19, 23-31; Saarenheimo, "Isojako," 364; Korhonen, "Koneiden aika alkamassa," 463; Viljo Rasila, "Torpparijärjestelmä," in Rasila et al., Suomen maatalouden bistoria 1, 365-66; Eino Jutikkala, "Tilalliset ja tilattomat," in Rasila et al., Suomen maatalouden bistoria 1, $448-50$.

17. Carl-Johan Gadd, Självbushaill eller arbetsdelning? Svenskt lant- och stadshantverk ca. 1400-1860 (Gothenburg: Gothenburg University, 1991), 305-6; Marja Uotila, Käsityöläinen kyläybteisönsä jäsenenä (Jyväskylä: University of Jyväskylä, 2014), 86-91, 324-25.

18. See Jacob Lundell, Om bandtverksskrain, näringsfribet och arbetets organisation (Lund, 1846).

19. "Men huru will man åwägabringa denna reform isynnerhet i ett land der kölden är en hwardags-gäst och enwisheten är ett nationens kännemärke? —i ett land der jordbrukaren, till och med emot sin wilja, är så isolerad, som Robinson på sin klippa i fordna tider, och om andra sina gelikar wet föga mer än att de finnas till. Det är rent omöjligt.” K.v.F., "Något om nyttan och nödwändigheten af Landtbruksmöten och skällskaper i Finland," Teknologen 2, no. 13 (28 Mar. 1846), 105-6.

20. "Öfverallt saknar man beräkning och plan, ordning och skönhet, konst i harmoni med natur-förhållanden, enkelhet och anspråkslöshet förenade med det nyttiga och nödvändiga. Främst drabbar dessa anmärkningar arkitekturen." "En flyktig blick kring landsbygden," Åbo Underrättelser, 4 June 1850, 2. 21. Editorial, Tidskrift för praktisk byggnadskonst och mekanik m.m. 1 (1850); "Några ord om byggnadsväsendet i landsorten," Tidskrift för praktisk byggnadskonst och mekanik m.m. 2 (1851), 55.

22. Carl Adolf Forselius, preface to Landtmanna-byggnader, by C. E. Löfvenskiöld (Stockholm: C. A. Forselius, 1854). See also C. H. Boheman and C. Stål, "Utlåtande öfver Herr C. E. Löfvenskjölds skrift: Om Landtmannabyggnader," in Handlingar rörande landtbruket och dess binäringar 1854 (Stockholm: Kongl. Svenska Landtbruks-Akademien, 1855), 178.

23. C. E. Löfvenskiöld, Landtmannabyggnader hufvudsakligen för mindre jordbruk (Stockholm: P. A. Norstedt \& Söner, 1868).

24. On the transnational agrarian reform of this period, see Peter M. Jones, Agricultural Enlightenment: Knowledge, Technology, and Nature, 1750-1840 (Oxford: Oxford University Press, 2016); on the reform in Sweden, see Staffan Högberg, Kungl. Patriotiska Sällskapets historia med särskild bänsyn till den gustavianska tidens agrara reformsträvanden (Stockholm: P. A. Norstedt \& Söner, 1961).

25. "London," London Evening-Post, 15 July 1762, 1.

26. The most popular of these eighteenth-century plan drawings, the ones by Carl Wijnblad, were meant to be adapted to local circumstances throughout the Swedish kingdom. A plan for a Finnish peasant's barn by professor of theology and gentleman farmer Jacob Tengström, completed as a competition entry for the Finnish Economic Society, was published in 1803. Carl Wijnblad, Beskrifning huru allmogens bygnader, af sten, som träd, måge med största besparing upföras enligt bifogande project-ritningar uti sex koppar-stycken, samt förslager uppå nödiga bygnings-ämnen (Stockholm, 1766); Försök till lärobok $i$ landthushällning för finska bonden (Åbo, 1803). On early plans for Swedish farm buildings, see Lange, Ladugirden, 78-79, 88-89; Johan Theodor Bergelin, "Om åbyggnad till stat-torp," Tidskrift för Svenska Landtbruket och dess Binäringar 1 (Jan. 1855), 28.
27. Jean-Philippe Garric, Vers une agritecture: Architecture des constructions agricoles (1789-1950) (Brussels: Éditions Mardaga, 2014), 70-71.

28. Joseph Gandy, Designs for Cottages, Cottage Farms and Other Rural Buildings; Including Entrance Gates and Lodges (London, 1805), vii.

29. César Daly, "Introduction," Revue générale de l'arcbitecture et des travaux publics 1, no. 1 (1840), 3-6.

30. "Allmänna Besvärs- och Ekonomi-Utskottets Betänkande no. 4," in Bihang till Samtlige Riks-Staindens protokoll vid Lagtima Riksdagen i Stockholm Ären 1859 och 1860, vol. 8 (Stockholm, 1860), 2.

31. "Allmänna Besvärs- och Ekonomi-Utskottets Betänkande no. 4"; Tidskrift för byggnadskonst och ingeniörvetenskap (1861), 17-18; Tidskrift för byggnadskonst och ingeniörvetenskap (1864), 55.

32. The Swedish competition received one entry, which was disqualified, and the Finnish competition received no entries. On the Swedish competition, see Ulrich Lange, Experimentalfältet: Kungl. Lantbruksakademiens experiment- och försöksverksambet på Norra Djurgården i Stockholm 1816-1907 (Stockholm: Kungl. Skogs- och Lantbruksakademien, 2000), 269; Lange, Ladugården, 122. In Sweden, similar competitions were held in the early $1860 \mathrm{~s}$. See, for example, "Förslags-ritningar till större och mindre bondgårdar," Tidskrift för byggnadskonst och ingeniörvetenskap (1864), 82.

33. "Helsingfors," Helsingfors Dagblad, 21 June 1862, 1.

34. Plan- och fasadritningar till landtmannabyggnader prisbelönta af Nylands och Tavastehus Läns Landtbruks-sällskap. Pinta ja etupuolen-kaavoja maamiesten rakennuksille, Uudenmaan ja Hämeen Lä̈nien Maaviljelys-Seuran palkitsemia (Helsinki, 1864); "Tillkännagifvande," Helsingfors Dagblad, 2 Apr. 1864, 3; "Ritningar till landtmanna-byggnader," Folkwännen, 15 June 1864, 1; Minutes of the Uusimaa and Häme Provincial Agricultural Society 3.10.1863, Archive of the Uusimaa and Häme Provincial Agricultural Society, Ministry of Agriculture KD 1/164 1864 \& KD 4/164 1864, National Archives, Helsinki.

35. Chiewitz died in December 1862. The society required some changes to his drawings, and Chiewitz's widow assigned the task to architect Carl Johan von Heideken. Annual Report and Minutes of the Uusimaa and Häme Provincial Agricultural Society 26.1., 29.1., 7.4., and 29.6.1863, Archive of the Uusimaa and Häme Provincial Agricultural Society, National Archives, Helsinki.

36. "Plan- och fasadritningar till landtmannabyggnader," Åbo Underrättelser, 11 June 1864, 3; "Ritningar till landtmanna-byggnader," 1.

37. Plan- och fasadritningar till landtmannabyggnader prisbelönta af Nylands och Tavastebus Läns Landtbruks-sällskap, 2.

38. "Ken sen mukaan tahtoo rakentaa, saapi sen tehdä." Beskrifning öfver planoch fasadritningar till landtmannabyggnader, prisbelönta af Nylands och Tavastebus Läns Landtbruks-sällskap. Pinta- ja etupuolen-kaavoja maamiesten rakennuksille, Uudenmaan ja Hämeen Läänien Maanviljelys-Seuran palkitsemia (Helsinki, 1864), 6.

39. "Dekoration för redan byggda stugor å landet," Tidskrift för praktisk byggnadskonst och mekanik m.m. 1 (1850), 17-18. The same argument was repeated in other publications, such as P. G. Sundius, "Notiser i praktisk byggnadskonst," in Landtbruks-arkitektur: En samling af till en del redan utförde byggnader på landet (Stockholm: J. Theod. Bergelin, 1858-59), 10.

40. See, for example, "Om wigten af landtmanna binäringars alfwarliga idkande," Teknologen, no. 11 (14 Mar. 1846); A. P. von Sydow, "Något om husbehofsbränningens skadlighet uti ekonomiskt hänseende," Teknologen, no. 4 (23 Jan. 1847), 25; "Om brännvinsbränningens skadliga inflytande på landtbruket och boskapsskötseln,” Teknologen, no. 46 (4 Nov. 1848), 361; C. E. Löfvenskiöld, "Meijeri," in Landtmanna-byggnader (Stockholm: C. A. Forselius, 1854), 35 .

41. Jean-Philippe Garric and Valérie Nègre, "Les campagnes réinventées," in La ferme réinventée: Constructions agricoles $d u X I X^{e}$ siècle, ed. Jean-Philippe Garric and Valérie Nègre (Nantes: Editions du Conseil Général de LoireAtlantique, 2001), 12. 
42. T. D. W. Dearn, Sketches in Architecture; Consisting of Original Designs for Cottages and Rural Dwellings, Suitable for Persons of Moderate Fortune, and for Convenient Retirement; with Plans and Appropriate Scenery to Each (London, 1807), v.

43. P. F. Robinson, Designs for Farm Buildings, 2nd ed. (London: Henry G. Bohn, 1837), design I. See also C. E. Löfvenskiöld, "Sammanbyggd tvätt-, brygg-, bakstuga och kölna m.m.," Tidskrift för byggnadskonst och ingeniörvetenskap (1861), 5; A. W. Edelsvärd, "Detaljer till landtmannabyggnader af trä," Tidskrift för byggnadskonst och ingeniörvetenskap (1862), 49.

44. A. J. Downing, "Hints on the Construction of Farm-Houses" (1846), in Andrew Fackson Downing: Essential Texts, ed. Robert Twombly (New York: W. W. Norton, 2012), 57-58.

45. J. H. Hammond, The Farmer's and Mechanic's Practical Architect; and Guide in Rural Economy (Boston: John P. Jewett and Company, 1858), 42.

46. Hammond, 41, 129, and plate XXIV.

47. See, for example, Forselius, preface; Löfvenskiöld, "Sammanbyggd tvättbrygg- bakstuga och kölna m.m.," 5; A. W. Edelsvärd, "Detaljer till landtmannabyggnader af trä," Tidskrift för byggnadskonst och ingeniörvetenskap (1861), 6; Edelsvärd, "Detaljer till landtmannabyggnader af trä," (1862), 49; A. W. Edelsvärd, "Försök till modell-boningshus för landtgårdar af olika storlek," Tidskrift för byggnadskonst och ingeniörvetenskap (1863), 161; Löfvenskiöld, Landtmannabyggnader hufoudsakligen för mindre jordbruk, 8.

48. "Strödda meddelanden om konstruktionssätten för byggnader på landet," Tidskrift för praktisk byggnadskonst och mekanik m.m. 4 (1853), 27.

49. Swedish examples of this include C. E. Löfvenskiöld, "Ornamenter m.m.," in Landtmanna-byggnader, 42; Löfvenskiöld, Landtmannabyggnader bufvudsakligen för mindre jordbruk, 21; P. G. Sundius, "Bro öfver ett mindre vattendrag," Tidskrift för Svenska Landtbruket och dess Binäringar (1856), 370.

50. C. E. Löfvenskiöld, "Bättre boningshus för tvenne arbetare-famijer å landet," Tidskrift för Svenska Landtbruket och dess Binäringar (1855), 152.

51. C. E. Löfvenskiöld, "Hemmansbostäder och dagsverkstorp," in Landtmanna-byggnader, 21.

52. Sundius, Landtbruks-arkitektur, 13.

53. Louis Bouchard-Huzard, Traité des constructions rurales et de leur disposition, vol. 2, 2nd ed. (Paris, 1869), 807.

54. See, for example, John Ruskin, The Seven Lamps of Architecture (London: Smith, Elder, 1849); John Ruskin, The Stones of Venice, 3 vols. (London: Smith, Elder, 1851-53); Owen Jones, The Grammar of Ornament (London: Day \& Son, 1856); Ralph Wornum, Analysis of Ornament, the Characteristics of Styles: An Introduction to the Study of the History of Ornamental Art (London: Chapman and Hall, 1856); Gottfried Semper, Über die formelle Gesetzmässigkeit des Scbmuckes und dessen Bedeutung als Kunstsymbol (Zurich, 1856). For analysis of these publications, see Ariane Varela Braga, Une théorie universelle au milieu du XIX ${ }^{e}$ siècle: "La Grammar of Ornament" d'Owen fones (Rome: Campisano Editore, 2017).

55. Alina Payne, From Ornament to Object: Genealogies of Architectural Modernism (New Haven, Conn.: Yale University Press, 2012), 32.

56. "La bienséance exige qu'un édifice n'ait ni plus ni moins de magnificence qu'il n'en convient à sa destination; c'est à dire, que la décoration des bâtiments ne doit pas être arbitraire, qu'il faut qu'elle soit toujours relative au rang \& à la qualité de ceux qui l'habitent, \& conforme à l'objet que l'on a en vue," wrote Marc-Antoine Laugier in his Essai sur l'architecture (Paris: Duchesne, 1753), 177. On bienséance, see Werner Szambien, Symétrie goût caractère: Théorie et terminologie de l'architecture à l'âge classique 1550-1800 (Paris: Picard, 1986), 92-98.

57. Löfvenskiöld, "Ornamenter m.m.," 42.

58. A. W. Edelsvärd, Landtbyggnadskonstens utveckling i Sverige under de sednaste årtiondena (Stockholm: P. A. Norstedt \& Söner, 1869), 28.

59. "Hvad rörer formen på vindbräden samt fönster- och dörrfoder, är vigtigt att dervid hålla ett visst lagom, så att dessa orneringar icke öfvergå till ett omotiveradt krims-krams eller urarta till en slags sockerbagarstil.” Johan Theodor
Bergelin, "Ornamenter för byggnader i trästil," Tidskrift för Svenska Landtbruket och dess Binäringar 1, no. 12 (Dec. 1855), 365.

60. See Caroline Heering, "Questionner l'ornement," in Questions d'ornements $X V^{e}-X V I I I^{e}$ siècles, ed. Ralph Dekoninck, Caroline Heering, and Michel Lefftz (Turnhout: Brepols, 2013), 16.

61. Downing, "Hints on the Construction of Farm-Houses," 55.

62. A. J. Downing, The Architecture of Country Houses: Including Designs for Cottages, and Farm-Houses, and Villas (1850; repr., New York: Dover, 1969), 140. 63. Sundius, "Notiser i praktisk byggnadskonst," 10. Sundius lived and worked in Finland for many years in the 1850s; his publications include several notices by Finnish owners of large estates.

64. Löfvenskiöld, "Ornamenter m.m.," 42-43; C. E. Löfvenskiöld, "Förslag till torpstuga, i skogstrakt, för svenska, indelta armén," Kongl. Landtbruks Akademiens Tidskrift, no. 1 (Jan. 1862), 272; Löfvenskiöld, Landtmannabyggnader bufvudsakligen för mindre jordbruk, preface, 14.

65. C. E. Löfvenskiöld, "Svinhus," in Landtmanna-byggnader, 32; C. E. Löfvenskiöld, "Ladugårdar," in Landtmannabyggnader bufvudsakligen för mindre jordbruk, 19.

66. P. G. Sundius, "En ladugård för 31 kor, 1 tjur, 8 ungnöt och 4 à 5 kalfvar," in Landtbruks-arkitektur, 25-31. This publication was probably the by-product of a commission Sundius received from the Swedish Agricultural Academy to design a model barn for an experimental farmstead in Stockholm. Lange, Ladugairden, 199-120.

67. "Men lägg till några vinteraftnars arbete, uppsätt dessa obetydligheter, och den lilla prydliga boningen skall för sina innevånare blifva oändligen mycket kärare." Sundius, Landtbruks-arkitektur, 13.

68. Edelsvärd, Landtbyggnadskonstens utveckling $i$ Sverige, 27.

69. See, for example, Löfvenskiöld, “Ornamenter m.m.”; Löfvenskiöld, Landtmannabyggnader hufvudsakligen för mindre jordbruk.

70. Ludwig Degen, Motive zu ornamentalen Zimmerwerken (Munich: Max Ravizza, 1857); and the French edition, Louis Degen, Motifs de décoration et d'ornement des constructions en bois (Paris: A. Morel, 1860).

71. Löfvenskiöld's unpublished manuscripts contain copies from Degen's Motive zu ornamentalen Zimmerwerken, but his publications include variations on Degen's designs, not copies. Edelsvärd published some of Degen's designs without citing his sources in a series of articles titled "Detaljer till landtmannabyggnader af trä" (Details to wooden farm buildings), published in Tidskrift för byggnadskonst och ingeniörvetenskap (1861-63). For a comprehensive presentation of the continental sources of Nordic mid-nineteenth-century architects, see Eldal, Historisme i tre. On the use of German pattern books in midnineteenth-century Sweden, and Degen's book in particular, see Atmer, Sommarnöjet i skärgården, 310-12.

72. Payne, From Ornament to Object, 263.

73. Payne, 111.

74. Löfvenskiöld, Landtmannabyggnader hufvudsakligen för mindre jordbruk, 40.

75. On the compendiums and grammars of ornament, see René Labrusse, "Grammars of Ornament: Dematerialization and Embodiment from Owen Jones to Paul Klee," in Histories of Ornament: From Global to Local, ed. Gülru Necipoğlu and Alina Payne (Princeton, N.J.: Princeton University Press, 2016), 320-33.

76. Quoted from the statutes of the Swedish Society of Handicraft in Sofia Danielson, Den goda smaken och sambällsnyttan: Om Handarbetets Vänner och den svenska hemslöjdsrörelsen (Stockholm: Nordiska Museet, 1991), 25. Broader than the concept of "handicraft," the Swedish term slöjd implied the education of the lower classes.

77. In 1846, an anonymous writer explained that it was truly impossible to distinguish between "factory industry" and "handicraft industry." "Om industrien i allmänhet, och den Finska isynnerhet," Teknologen, no. 15 (11 Apr. 1846), 121. 
78. Löfvenskiöld, "Ornamenter m.m.," 42.

79. Edelsvärd, "Detaljer till landtmannabyggnader af trä" (1862), 9.

80. "Att uppmuntra husfliten är ett af de kraftigaste medlen att utrota tiggeriet och sedeslösheten i sin grund; ty flit och ständig sysselsättning föda wälmåga och sedlighet. De personer som genom afsättning af hemslöjdens produkter, uppmuntra den, göra derföre sitt land en stor tjenst. Och säkert är, att de socknar der den fattige har tillfälle att genom arbete försörja sig, der finnas och mindre fattighjon och lösdrifware." "Om wigten af landtmanna binäringars alfwarliga idkande," 90.

81. "Husflit och näringsfrihet äro grunderne till Wälstånd," Teknologen, no. 6 (6 Feb. 1847), 41-43.

82. Hvattum, Heinrich Ernst Schirmer, 110-35; Hvattum, "Panoramas of Style." 83. César Daly was explicit about this. In 1841, describing the plans of Ornässtugan, a wooden building in Sweden, he claimed that its decorative bargeboards and finials were found on every medieval wooden house in Europe. César Daly, "Maison suédoise en bois (XV s.)," Revue générale de l'architecture et des travaux publics, no. 8 (1841), 405.

84. For example, see the design for a double house by Edelsvärd in Löfvenskiöld, Landtmannabyggnader hufvudsakligen för mindre jordbruk, 13.

85. Siegfried Kracauer, The Mass Ornament: Weimar Essays (Cambridge, Mass.: Harvard University Press, 1995).

86. "Men hur intagande den än är, huru mycket skulle den ej vinna, om dessa bostäder, äfven de obetydligaste, allestädes uppfördes ändamålsenligt och ikläddes dessa lätta och behagliga former, som verka så välgörande på sinnet? - Vid föreställningen om en sådan allmän förändring och all den nytta och trefnad den skulle medföra . . . , hvem kan underlåta att af varmaste hjerta önska fäderneslandet en sådan framtid!” Löfvenskiöld, Landtmannabyggnader bufvudsakligen för mindre jordbruk, 10.

87. Fernlund, "'The Demands of the New Age,'” 283.

88. C. E. Löfvenskiöld, "Några ord om landtbyggnadskonstens utveckling i landet under de sista 30 åren,” in Edelsvärd, Landtbyggnadskonstens utveckling i Sverige, 16; Svala, Lantbruksarkitekten Charles Emil Löfvenskiöld, 198; Lange, Ladugården, 106-7.

89. Kim Björklund, Nylands Svenska Lantbrukssällskap 1856-2006 (Helsinki: Nylands Svenska Lantbrukssälsskap, 2005), 101.

90. "Huoneen rakennuksesta talonpoikaisilla tiloilla," Lukemisia Maamiebille 1 , no. 6 (1849), 265.

91. See, for example, Barbara Miller Lane, National Romanticism and Modern Architecture in Germany and the Scandinavian Countries (Cambridge: Cambridge University Press, 2000).

92. On the notion of kosmos_-often translated as ornament - as an artifact completing and correcting the world in convenient ways, see Michel

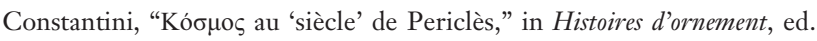
Patrice Ceccarini, Jean Loup Charet, Frédéric Cousinié, and Christophe Leribault (Paris: Klincksieck/Rome: Académie de France à Rome Villa Medicis, 2000), 35-50. 